Case Study.

\title{
Households Livelihood Coping Strategies in the Urban Informal Settlements the Case of Mlalakuwa, Dar-es-Salaam Tanzania.
}

\author{
Dennis N.G.A.K. Tesha \\ Department Of Building Economics,
} ARDHI University (ARU), P.O. Box 35176, Dar-es-Salaam, Tanzania.

\begin{abstract}
:
This paper explores various households livelihood coping strategies in the urban informal settlement of Mlalakuwa in Dar-es-Salaam, Tanzania. It employed a case study method in the urban informal settlement of Mlalakuwa. Multiple data collection tools were employed, in which semi-structured interviews with key informants, field observations, sketches, mapping and photographic registration, were used in collecting primary data through household survey, while literature review, was used in collecting secondary data. Descriptive statistical and content analysis were employed in data analysis. The paper revealed that; households in the study are involved in a lot of livelihood activities, such as urban agriculture and livestock keeping (i.e. pigs, chicken and cow), as well as trading these goods in the market, shop keeping, selling pharmaceutical, monetary services (banks, and mobile money), local drink brewing, running female and male hair dressing saloons as well as selling their products, vehicle and motor cycles repairing, milling machines, taxi-running and driving, motor cycles-running and driving, mobile shoe shining and mending, food processing and vending, food product street hawking, fish and meat butchery, selling fuel wood and charcoal, tailoring and cloth retailing, carpentry, welding and metal working, bricks and pavement material making, building materials retailing, oil and gas trading, etc. Drawn by combining both tangible and intangible assets, as a strategy in coping with life stress and shocks. It argues that the informal economy plays a crucial role not only for the lower income earners, but also the middle and higher income earners, with everyone depending on one another, in different livelihood activities. Living together in one area, the three income earning groups, engages themselves in agricultural (farm) and non-agricultural (non-farm), monetary (economics) or non-monetary (non-economics), livelihood activities which all ernes them capital, as coping strategy against life stress and shocks. The paper concludes that; the households in the Mlalakuwa urban informal settlement, survives by combining various assets as a livelihood coping and recovery strategies based on their indigenous strategies and knowledge, so as to recover from daily life stress and shocks.
\end{abstract}

KeyWords: Households, Livelihood, Coping Strategies, Informal Settlements, Mlalakuwa, Dar-es-Salaam.

\subsection{Introduction:}

Globally, it has been noted that; each day, about 193,107 new urban dwellers are added to the world's urban population UN-Habitat, (2009). Basically, in 1976, one third of the world's population lived in urban areas. Thirty years later, in 2007 up to 2012 , the figure had risen to $50 \%$ of the world population, i.e. 7 billion, and it is expected to increase to 9 billion in the next decades (i.e. More than $70 \%$ ) by 2050 , due to fast urbanization, making the world urban population to reach $70 \%$ of the world population, (i.e. two-thirds of humanity living in towns and cities) Lupala, (2002); OECD, (2006); Abebe, (2011); UN-Habitat,
(2011); OECD, (2011); UN Habitat, (2012); Rasmussen, (2013); UNHSP, (2010) in Oluwafemi, (2013); UN-Habitat, (2004) in Ekandem, et al., (2014); and Teyanga \& Mrema, (2018). Writings by UN-Habitat, (2008); Mundy \& du Plessis, (2010); and UNHSP, (2010) in Oluwafemi, (2013) shows that; over one third of the world's urban population, live in informal settlements with high incidence of urban poverty, and the number has been and keeps on increasing.

This enormous rise in global urban population, along with fast urbanization, has led to emergency, rapid growth in size and an increase in number on 
new settlements whereby most of them are taking place informally in developing countries, hosting mostly the urban poor, OECD, 2011 in Sakijege, (2013), Teyanga \& Mrema, (2018); and Kikwasi \& Mbuya, (2019). Moreover, the hosted urban poor, end-up in informal settlements, due to not being able to meet their accommodation and service needs through formal mechanisms, (OECD, 2006; UNHabitat, 2009; OECD, 2011) in Sakijege, et al., (2014). UN-Habitat, (2007) in Amendah, et al., (2014); UN-Habitat, (2009) in Abu-Salia, et al., (2015); Abu-Salia, et al., (2015); and UN-Habitat, (2015) in Msuya, et al., (2017), accounts that; about $90 \%$ of the world's informal settlements are in developing countries, accommodating $25 \%$ to $32 \%$ urban population.

Moreover, Kyessi, (2002); Parsa, et al., (2011); Henderson, et al., (2013); and UN-Habitat, (2009) in Abu-Salia, et al., (2015), asserts that; the informal settlements in the Sub-Saharan Africa countries, which have been urbanizing much more rapidly, than the rest of the world, are estimated to accommodate a total of up to $72 \%$ of urban population. This is due to the fact that; the proportion of Africans living in urban areas increased from $15 \%$ in 1950 to $39 \%$ in 2010 and is expected to rise to $43 \%$ in 2020 , UN, (2011) in Amendah, et al., (2014). The trend of population growth for selected Sub-Sahara African cities show that; the urban population growth in Africa remains the highest in the world (UN-Habitat, 2010; World Population Data Sheet, 2013; World Bank, 2016) in Kikwasi \& Mbuya, (2019). According to UNHabitat, (2010); Ricci, (2019); and Kikwasi \& Mbuya, (2019); the Sub-Sahara Africa population exceeded 1 billion in 2009, with 395 million, almost $40 \%$ of the urban population, living in cities. The urban population is expected to double from to 1.1 billion in 2040, and to 2.4 billion in 2050 , by which time $60 \%$ of all Africans will be living in cities.

These higher growth rates, at an average rate of $4.5 \%$ per annum, are projected to continue into the next two to three decades, Kikwasi \& Mbuya, (2019), thus adding much pressure on the urban settlements and infrastructures, as well as urban households to live in informal settlements, UNHabitat, (2010). According to UN-Habitat, (2010); URT, (2012); Kalugila, (2014); and Teyanga \& Mrema, (2018), the informal urbanization ${ }^{1}$ trends in

Urbanization; is simply the movement of people from rural to urban areas in search better life, Kikwasi \& Mbuya, (2019).
Sub-Saharan Africa, show Tanzania to be one of the countries with the highest urban population living in informal settlements, i.e. Over $70 \%$, followed by Mozambique and Ethiopia. This informality, is caused by the rapid urbanization, due to its attraction of informal settlements in urban areas, Ojong, (2011); and Kikwasi \& Mbuya, (2019). Essentially, the urban population is growing at a rate of $6 \%$ per annum, which is about twice the Tanzania national rate of population growth, making it the one of the fastest in the world, which has seen its population growing from 12,313,469 persons in the 1967, 44,928,923 in 2012, $51,557,365$ in 2016 and 58.552 million people in 2020, URT, (2013); UNDP, (2015); URT, (2016); Kiondo \& Mosha, (2017); CIA, (2020); and Mosha, (2017). The growth in urban population, has seen an overwhelming evolution and rapid proliferation of informal settlements in size and number, with DarEs-Salaam alone, accommodating more than 150 informal settlements, with a population density of 3,133 people per square kilometer (URT, 2012); Kyessi, (2013); and Ricci, (2019).

These urban informal settlements are densely populated and accommodate high, middle and lowincome socio-economic groups, who as a strategy, cope with life stress and shocks by combining numerous livelihood activities, Kalugila, (2014); and Kalugila \& Mbisso, (2018). Dercon, (2002) in Endris, et al., (2017), asserts that; households always face stress and shocks, both natural and man-made, and often devise their own responses and collective institutional strategies to cope with and recover from them. The way a household copes with and withstands economic stress and shocks, depends on the options available in terms of capabilities, assets (including both material and social resources) and activities, i.e., on the household livelihood strategy they draw to make a living, Ellis, (1998). DFID, (1999) clarifies that; shocks can destroy assets directly (in the case of job loss, death of one of the head of the household (i.e. Husband or wife), death of livestock, forced eviction, being in massive debt, house being auctioned, floods, storms, civil conflict, etc.), forcing households to abandon their home areas and dispose of assets (such as land) prematurely as part of coping strategies.

Furthermore, households may pursue a range of activities for a living which include but not limited to agriculture or non-agriculture or both, and are 
considered poor, when the resources they command are insufficient, to enable them to consume sufficient goods and services, in order to achieve a reasonable minimum level of welfare, Rakodi\& Lloyd-Jones, (2002); and Cephas \& Bernard, (2012).

The hidden households livelihood coping strategies in the informal settlements, have been receiving less attention from the housing and urban planning stakeholders. A number of key studies by Kombe \& Kreibich, (2000); Nguluma, (2003); Sheuya, (2004); Limbumba, (2010); Rweyemamu, (2013); Kalugila, (2014); Hamdi, (2017); Kalugila \& Mbisso, (2018); and Mbisso \& Kalugila, (2018), on the urban informal settlements in Dar-es-Salaam Tanzania, have been focusing on the housing settlement, its transformation, modification, housing location choice, or land and types of landed properties preferences by developers. However; little is known, given less focus and documentation that has been done on this fraction. Thus, this paper aimed at exploring households livelihood coping strategies in the urban informal settlement of Mlalakuwa, in Dares-Salaam, Tanzania; by examining exactly what are the existing household's agricultural, nonagricultural, monetary and non-monetary livelihood activities, that are engaged singly or in combination, as strategies within the Mlalakuwa urban informal settlement, in order to cope against life stress and shocks. The study employed measurements of the five livelihood assets, derived from the DFID sustainable livelihood guidance sheets, DFID, (1999), as seen in Fig. 2.01.

\subsection{Conceptualizing Households and Livelihood Coping Strategies:}

\subsection{The Conceptualization of Household:}

There are multiple definition when it comes to households as a terminology. But for this study; a household is a group of persons (i.e. one or more people), at the same address or house, who share common provision of food and eating arrangements, shelter and other essentials for living, for at least one meal per day, UN, (2008) in OECD, (2013); Haviland, (2003); and UN, (2017). It is either a group of persons who live together and share expenditures (including the joint provision of the essentials of living), finance and or an individual person living alone, SNA, (2008) in OECD, (2013). Basically, households may contain one, two or more nuclear families within them, but also household members other than members of the nuclear family, such as more distant relatives, friends, fosterchildren, lodgers, flat-mates, long-stay guests or visitors. Moreover, it must be understood that; a house is considered to contain multiple households, if meals or living spaces are not shared.It may occupy the whole, part of, or more than one housing unit, or be found in collective living quarters, or be homeless UN, (2008) in OECD, (2013). Haviland, (2013), defines householdsas the basic residential unit in which economic production, consumption, inheritance, child rearing, and shelter are organized and carried out. In economics, a household is a person or a group of people living in the same residence.

Furthermore, a household ${ }^{2}$ comprises either one person living alone, or a group of people, who may or may not be related, living (or staying temporarily) at the same address, with common housekeeping, who either share at least one meal a day or share common living accommodation (i.e. a living room or sitting room). This includes resident domestic servants. Members of a household are not necessarily related by blood or marriage. A household is distinct from the less inclusive category of family. A family is defined as either a married or cohabiting couple on their own, or with their never-married children who have no children of their own, or lone parents with similar such children. Members of a family are related by blood, adoption or marriage. UN, (2017), clusters average households into two groups, i.e.

Fig. 1.01: the Global Average Household Size and Composition (Most Recent Data Since 2000).

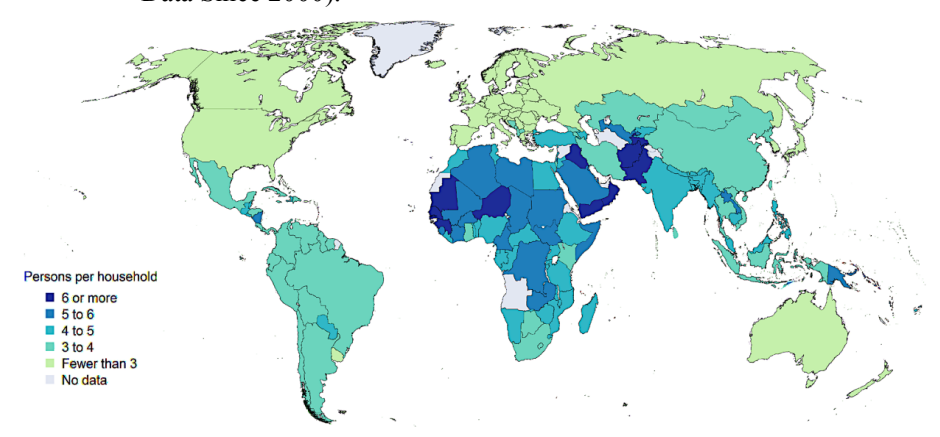

Source: UN, (2017),

Small average household ${ }^{3}$ sizes, which are those with fewer than three persons per household, normally concentrated in europe and northern

\footnotetext{
${ }^{2}$ https://ukdataservice.ac.uk/media/262992/discover_qbcommentary_househol ds thomas.pdf

${ }^{3}$ Average Household Size; - is the average number of persons per household. At the aggregate national level, it is calculated by dividing the total household population by the number of households in a given country or area, UN, (2017).
} 
america; and large average household sizes, which are those with five or more persons per household, and are observed across much of africa and the middle east, (fig. 1.01). According to united state census; a household ${ }^{4}$ includes all the persons who occupy a housing unit (i.e. a house, an apartment, a mobile home, a group of rooms, or a single room) that is occupied (or if vacant, is intended for occupancy) as separate living quarters. Likewise, theoccupants ${ }^{5}$ may be a single family, one person living alone, two or more families living together, or any other group of related or unrelated persons who share living arrangements.a householder ${ }^{6}$ in the american community survey, united states census bureau of 2013; is the "person (or one of the people) in whose name the housing unit is owned or rented (maintained);" if no person qualifies, any adult resident of a housing unit is a householder. The united state government formerly used the term head of the household and head of the family to describe householders; beginning in 1980, these terms were officially dropped from the census and replaced with householder.

\subsection{The Conceptualization of Poverty:}

There are number of ways when it comes to defining poverty, because; the poor households are exposed to risk, limited opportunities to income generation, misery, crime, untimely death, fear, despondency depression, and suicide, (Okunmadewa, 1997; Olowonomi, 1997; Blank, 2003; \& Adeyeye, 2014) in Akeweta, et al., (2014). Coudouel, et al., (2002) in Rafea, (2017) report that; poverty is based on whether households or individuals possess enough resources or abilities to meet their current needs, as they combine their income, expenditures, consumption, health, education and other assets. Thus, it has political, social and economic implications Rafea, (2017). Moreover, Nolan \& Whelan, (1997) in Rafea, (2017) detail that; the poverty concept, has also been complemented by a range of other social indicators like, life expectancy, infant mortality, nutrition, the proportion of the household budget spent on food, literacy, school enrolment rates, access to health clinics or drinking water, to classify poor groups against a common index of material welfare. Those indicators or approaches have been developed through many years of practice by

\footnotetext{
${ }^{4}$ https://www.census.gov/housing/hvs/definitions.pdf

${ }^{5} \mathrm{https}: / /$ www.census.gov/quickfacts/fact/note/US/HSD310218

${ }^{6} \mathrm{http}: / /$ communityvitalsigns.org/wp-content/uploads/sites/19/2018/07/OurCo mmunityVitalSigns2013FinalReport.pdf
}

academics, social workers, economists and anthropologist who define and measure poverty in different ways, Nagi, (2010) in Rafea, (2017).

For this study, and in-line with writing by Sheuya (2004); (Yeboah, 2005 \& Vandenberg, 2006) in Makalle, et al., (2011); and Alison \& Mc Arearcy, (2013) in Akeweta, et al., (2014), poverty in economic terms; is a lack or deficiency of economic attributes such as income, capital, and assets; while in social and political terms, it is a lack of human capital (e.g. skills) as well as basic needs and necessities of life such as food, shelter, cloth, medical care or health, safety, inadequate access to basic infrastructures and services, housing, and education; and political participation and control over decisions that affect individuals. In existential terms, poverty is as a lack or deficiency of social capital, and networks (e.g. affection from friends and family and loved ones), exclusion and isolation from community matters. Moreover, it is seen as the result of policies, institutions and processes that are not supportive on achieving adequate livelihoods. The poverty concept remains dynamic, and thus different frameworks have been developed in order to gain deeper understanding of the households livelihoods, with sustainable livelihoods approach (fig. 2.01), being one of the framework. This is supported by the fact that; households may move in and out of poverty by mobilizing and managing the five assets (human, physical, financial, natural and social) at their command, Sheuya (2012).

\subsection{The Conceptualization of Livelihood:}

\subsubsection{Livelihood}

The concept of livelihood can be explained as "means of earning a living", or the activities undertaken by a family to obtain the basic materials needed to sustain household survival and development; and it is not just the net income or consumption, but the concept that directs attention to the way in which a living is obtained, and a wide range of activities, such as gaining and retaining access to resources and opportunities, dealing with risk, negotiating social relationships within the household and managing social networks and institutions within communities and the city Bengtsson \& Klerfelt, (2014); Scoones, (1998) in Han, Ba \& Xin, (2015); and Cai, (2012) in Xu, et al., (2015). Blackwood \& Lynch, (1994) in Ellis, (1999), assert that; it includes access to, and benefits derived from, social and public services 
provided by the state such as education, health services, roads, water supplies and so on. Moreover, it encompasses income, both cash and in kind, as well as the social institutions (kin, family, compound, village and so on), gender relations, and property rights required to support and to sustain a given standard of living, Ellis, (1999). According to Chambers \& Conway (1991); Chamber, (1995); Carney, (1998); Rakodi \& Lloyd-Jones, (2002); Sheuya, (2004); Eneyew \& Bekele, (2012); Oluwafemi, (2013); Scoones, (1998) in Han, Ba \& Xin, (2015); and Rafea, (2017), livelihood comprises the capabilities, assets (including both material and social resources) and activities required for a "means of gaining a living"; a livelihood is sustainable, when it can cope with and recover from stress and shocks, maintain or enhance its capabilities and assets, and provide sustainable livelihood opportunities for the next generation; at the local and global levels, and in the short and long term.

The term livelihood in most cases, is used in exploring the activities, assets and capabilities that conceptualize household's means of living, Ellis, (1999); and Bengtsson \& Klerfelt, (2014). Furthermore, households explore two groups of livelihood assets, which are the resources on which people draw in order to carry out their livelihood strategies, and meet their needs, Chambers \& Conway, (1991); and Eneyew \& Bekele, (2012). These assets include; tangible assets as those physical assets, that are owned (i.e. human capital, physical capital, natural assets and financial capital) and intangible assets, which are those assets that help men and women access other assets, that they do not directly own or have control over (i.e. social capital and political capital), Chamber, (1995); Ellis, (1999); Rakodi \& Lloyd-Jones, (2002); Frankenberger, et al., (2002); Farrington, et al., (2002); Sheuya, (2004); Rakodi, (2000); Limbumba, (2010); Eneyew \& Bekele, (2012); Bengtsson \& Klerfelt, (2014); Fang, et al., (2014); Akeweta, et al., (2014); Banks, (2015); Han, Ba \& Xin, (2015); Abu-Salia, et al., (2015); Bhattacharjee, (2016); Rafea, (2017); and Kassa, (2019). These capitals, constitute a stock of asset which can be stored, accumulated, exchanged, expended by putting them to use or investment or work to generate a flow of income as well as wealth, and lost; hence affecting a household's level of livelihood security, quality of life, and its options for coping strategies, Frankenberger, et al., (2002); and Babulo, et al., (2008) in Fang, et al., (2014).

DFID, (1999), exemplifies that; a single physical asset can generate multiple benefits. If someone has secured access to land (natural capital) they may also be well-endowed with financial capital, as they are able to use the land not only for direct productive activities but also as collateral for loans. Similarly, livestock may generate social capital (prestige and connectedness to the community) for owners while at the same time being used as productive physical capital (think of animal traction) and remaining, in itself, as natural capital. Nguluma (2013) ${ }^{7}$, adds that; these assets are in many ways interlinked, giving an example; when household sells their labour (human capital) they can receive cash money, which is the financial assets. With the money, they can buy houses (physical assets) and rent to earn money (financial asset), Nguluma (2013) also argues that sometimes house transformers, do not rent the room to tenants rather, they give them to their close relatives or grown up children at rent-free status (social capital). Despite the assets being interlinked, still households vulnerable to stress or risks, shocks, and seasonality from time to time, which force them to device the coping strategies, that can protect their livelihoods, and enable recovery, Rakodi \& Lloyd-Jones, (2002); and Oluwafemi, (2013).

These shocks, are adverse events that lead to the loss of household income and depletion or loss of productive assets, hence perpetuating poverty and vulnerability in most developing countries, Clarke \& Dercon, (2009) in Endris, et al., (2017). They can be idiosyncratic (i.e. those peculiar to a household, such as animal illness, injury or death e.g. in cows, goats, pigs, chickens, etc, illness, injuries or death to/of household head, spouse, or another person, unemployment, price fluctuation, Wedding and funeral expenses, or theft) and covariate or systemic (i.e. those affecting the wider community at the same time or same place, such as climatic shocks, natural disasters and crop loss caused by famine or epidemics), Endris, et al., (2017); Alderman \& Paxson, (1999) in Endris, et al., (2017).

\subsubsection{Households Livelihood Activities}

The members of a household combine their capabilities, skills and knowledge with the different

\footnotetext{
Nguluma, H.M., (2013); “A Livelihoods Approach; Conceptual Issues, Definitions and Household Strategies", a Lecture for the HS 723: Housing Poverty and Livelihood, to MSc. Housing at Institute of Humans Settlements Studies(IHSS), ARDHI University(ARU), Dar-es-Salaam, Tanzania.
} 
resources at their disposal to create activities that enable them, to achieve the best possible livelihood for themselves, Chambers \& Conway, (1991); and Eneyew \& Bekele, (2012). The created livelihood economic and non-economic activities that people know, own and undertake to earn income today and into the future; can be either, farm (agricultural) and non-farm (non-agricultural) which earn them monetary or non-monetary resources, Rakodi, (2002); Akeweta, et al., (2014); Bhattacharjee, (2016); and Kassa, (2019). They add that; farm (agricultural) includes, crop production (e.g. maize, beans, banana, onions, tomatoes, rice, coconut, all kind of vegetables, all kinds of fruits etc.), livestock keeping (cows, goats, pigs, sheep, ducks, chickens, etc.), while non-farm (non-agricultural) products include, tailoring, weaving, basket making, mat making, pottery, welding, carpentry, trading these goods in the market, wage or salary employment, and self-employment, rent income, transfers and remittances, natural resource extraction (mainly charcoal making), etc. Akeweta, et al., (2014), point-out that; monetary resources include earnings from formal or informal labor or financial support provided by the local or national authorities, while non-monetary resources include activities by household members to meet their own needs, informal relations of mutual support or the exchange of services, and goods or services supplied by official agencies.

\subsubsection{Livelihood Coping Strategies}

The concept of a livelihood strategy has become central to human livelihood and development practice in recent years, aiming at analyzing the strategies employed by households, in the attainment of livelihood outcomes, Eneyew \& Bekele, (2012). Basically, most households in informal settlements, depend on diverse portfolio of activities and income sources as a copping strategy, by combining different assets available in their locality, and by gaining access to use, and exercise control over any resources identified important for their well-being. Farrington, et al., (2002); Eneyew \& Bekele, (2012); Cephas \& Bernard, (2012); and FAO, (2005), in Fang, et al., (2014); affirm that; livelihood strategies denote the range and combination of activities and choices made by households, in order to generate a living and achieve their livelihood goals, or are the planned activities that men and women undertake to build their livelihoods, and earn them income in cash or kind. Livelihood strategies are determined by the assets and opportunities available to men and women as well as by the choices and preferences of men and women Farrington, et al., (2002). They further avows that; livelihood strategies, usually include a range of activities designed to build asset bases and access to goods and services for consumption, alongside being generally adaptive over time, responding to both opportunities, and changing constraints.

Besides, apart from including coping strategies designed to respond to stress and shocks (such as drought, floods, natural disaster, civil fighting, illness, death and policy failures) in the short term; livelihood strategies can be viewed as coping or adapting strategies, in which as strategies they can be understood as activities that redress short term surges in stresses and shocks, while as adapting strategies bases on the long term, and tend to be more resilient, (Scoones 1998 \& Benedikz, 2002) in Cephas \& Bernard, (2012). Additionally, Ellis, (1998); and Sheuya, (2004) add that; a livelihood strategy encompasses not only activities that generate income but many other kinds of choices, including cultural and social choices, that come together to make up the primary occupation of a household. These strategies change through time, due to many factors such as markets, new technologies, and climate. Furthermore, natural hazards, market uncertainties, political unrest, and government policies are among other forces that individuals, households, and communities have to negotiate to reduce their vulnerability and improve their welfare.

Livelihood coping strategies as per (Dercon, 2002; Dercon, 2006; Zimmerman, et al., 2003) in Akeweta, et al., (2014), (Browning \& Lusardi, 1996; Dercon, 2002; and Aquiar \& Hurst, 2005) in Amendah, et al., (2014) may have short-terms or long-term impacts, and can be classified into two categories; weak (ex-ante) coping strategies and active (ex-post) coping strategies. They exemplify that; the weak (ex-ante) coping strategies; include selling assets or properties or using up savings, promoting and selling labour force including that of children, reducing consumption patterns, reduction or restriction of family member's food intake; taking children out of school to reduce education expenditures, or postponing health care expenditures, relocating (migration) and/or restructuring households, while active (ex-post) coping strategies; includes mitigation action like, 
increasing home production or diversifying sources increasing of income, reducing expenditures and saving more, changing place of residence, finding supplementary work or second job, formal borrowing e.g., from banks or community-based social groups, petty trading and others.

\subsubsection{Sustainable Livelihood Framework}

The conceptual underpinnings and variables of livelihood have been well discussed by DFID from the Department of International Development, (DFID, 1999) of United Kingdom (UK), popularly referred to as the sustainable livelihood framework (fig. 2.01), Lupala \& Maglan, (2015). Ellis, (1999); and Bengtsson \& Klerfelt, (2014); define sustainable livelihood framework as the activities, the assets, and the access that jointly determine the living gained by an individual or household. It provides a comprehensive and complex approach, to understand the context on how people make a living; the capabilities and assets available for them (i.e. reserves, resources, claims, and entitlements); livelihood strategies they follow in the face of existing policies and institutions; livelihood outcomes they intend to achieve; alongside being used as a guideline on understanding a range of issues which are important for livelihoods, (Scoones, 1998; DFID, 2000; Kanji et al., 2005) in Eneyew \& Bekele, (2012); and Scoones, (1998) in $\mathrm{Xu}$, et al., (2015).

According to Akeweta, et al., (2014); Scoones, (1998) in $\mathrm{Xu}$, et al., (2015), and Bhattacharjee, (2016), a livelihood is said to be sustainable; when it can cope with, and recover from stress and shocks, and restore, maintain or enhance its capabilities and assets which determine living of an individual or group of people, both now and in the future, provide for next generations, and earn net income for the livelihood of others in both the long and short term, without damaging the natural basis. Sustainability of the livelihood is based on this livelihood outcome, (fig. 2.01), Bhattacharjee, (2016). According to livelihood framework, a household's livelihood and its level of well-being depends on the assets and or resources it has access to. The sustainable livelihood framework has an asset pentagon, which is the core content of the livelihood resources, that includes the five key variables of assets; i.e. financial, human, natural, physical, and social capital. If these assets are affected by either natural or man-made factors, then the livelihood of communities is threatened, Lupala
\& Maglan, (2015).

Fig. 2.01; the sustainable livelihood framework.

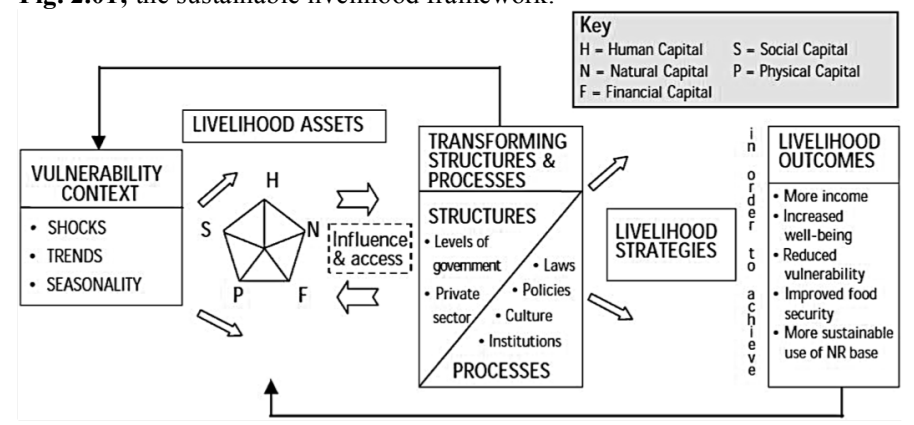

Source: Carney, (1998); DFID, (1999); \& UNDP, (2017).

The DFID sustainable livelihood framework identifies the vulnerability context to include trends, shocks and culture which act upon the capital assets. Lupala \& Maglan, (2015) enlengthens that; if the transforming structures interact well with capital assets, the emerging livelihood strategies leads to increased income, well-being, reduced vulnerability, improved food security and more sustainable use of non-resource base (fig. 2.01). The context of this paper as far as the DFID sustainable livelihood framework is concerned, gazes on; what are the households livelihood coping strategies in the urban informal settlement of Mlalakuwa, in Dares-Salaam, Tanzania?. This sustainable livelihood framework emphasizes the need to analyze factors that; influence household's livelihood coping strategies; affect both livelihood and the process; attempts to distinguish the main factors affecting livelihood and the interactions between them; and plays an important role in understanding livelihood, Fang, et al., (2014); and $\mathrm{Xu}$, et al., (2015).

\subsection{METHODOLOGY}

The study involved understanding the households livelihood coping strategies, by looking at the livelihood activities, the available five capital assets and capabilities that households engage against the stress and shocks, as the means of gaining living. In exploring these variables; a case study strategy approach was used.

\subsection{Dar-es-Salaam and its Informal Settlements ${ }^{8}$}

Dar-es-Salaam, a coastal city which originally was a small village named Mzizima (i.e. healthy town)

\footnotetext{
${ }^{8}$ Other terms used to describe the informal settlements are Favelas, (Brazil); Shanty Towns, (English-speaking Africa); Barriadas, (Peru); Bidonvilles, (former French colonies); Callampas or Campementos, (Chile); Gecekondu, (Turkey); Villas Misarias, (Argentina); Katchi Abadis, (Pakistan); Kampungs, (Indonesia); Ranchos (Venezuela); Colonias Letarias, (Mexico); Barong-Barong, (Philippines); Bastee and JuggiJohmpri, (India); Kevettits, (Burma), Abebe (2011); and Kalugila, (2014).
} 
that began as a fishing village in the mid-19th Century, before gradually becoming an established port and trading center; is the capital city; the largest city; the most important commercial and manufacturing centre in the United Republic of Tanzania; and one among the third fastest growing cities in Sub-Saharan Africa, Mshumbusi, (2011); Kiunsi, (2013); URT, (2016a); URT, (2016b); Mosha, (2017); and Ricci, (2019).

Fig. 3.01; the location of Dar-es-Salaam City, within the United Republic of Tanzania.

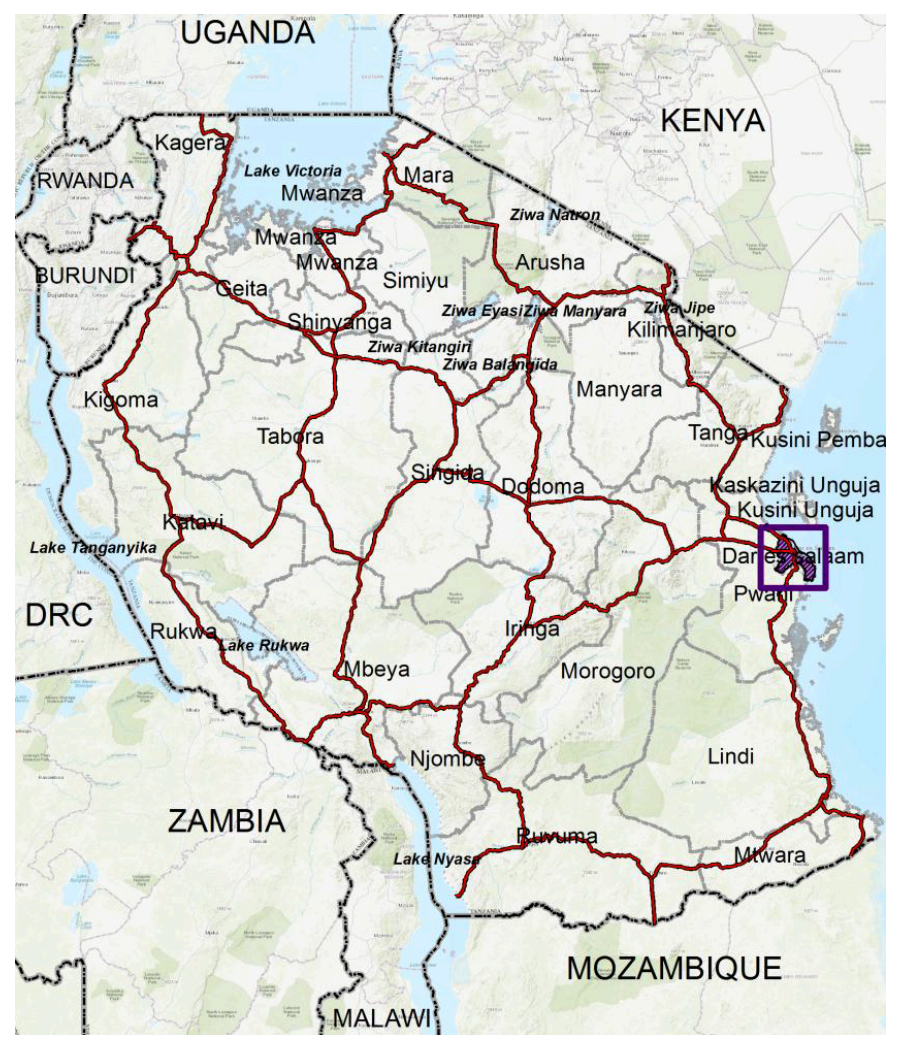

Source: URT, (2016a),

Fig. 3.02; the existing five districts within Dar-es-Salaam City, and the study

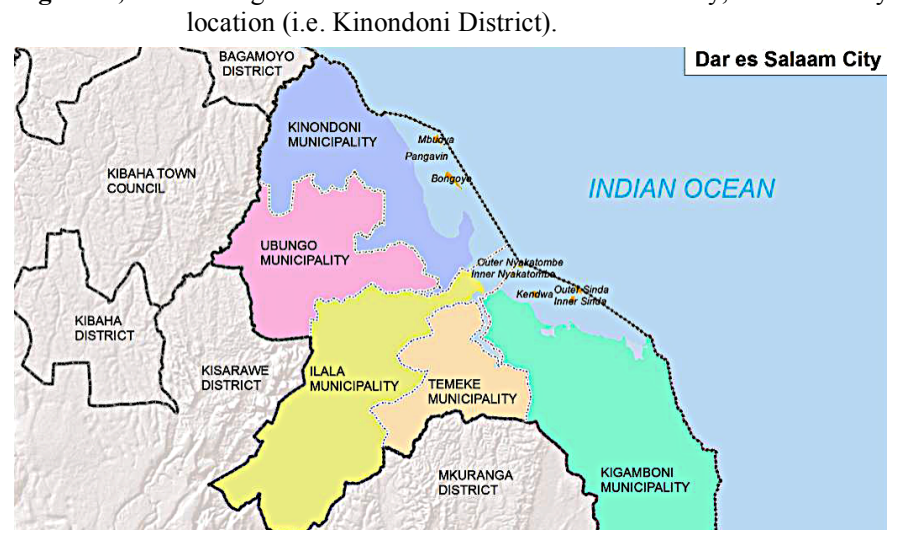

Source: URT, (2016a).

The city, apart from being bordered by the Coast Region to the north, west and south; it is located along the East African Coast of the Indian Ocean (fig. 3.01), in the Eastern part of the Tanzanian mainland, at $6^{\circ} 45^{\prime} \mathrm{S}$ and $7^{\circ} 25^{\circ e} \mathrm{~S}$ latitude, $39^{\circ} 18^{\prime} \mathrm{E}$ and $39^{\circ} 55^{\mathrm{ce}} \mathrm{E}$ longitude, and separated from the island of Zanzibar by the Zanzibar Channel, Mshumbusi, (2011); Kiunsi, (2013); and URT, (2016a). Moreover, Dar-es-Salaam is a cosmopolitan city, with a total of 1,393 square kilometers of landmass, which is only $0.19 \%$ of Tanzania Mainland's area; stretching about 100 kilometers between the Mpiji River to the North, and beyond the Mzinga River in the South, with a complex social, cultural and economic environment, Mshumbusi, (2011); and Kiunsi, (2013).

Administratively, Dar-es-Salaam city has five Municipalities i.e. Ilala, Kinondoni, Temeke, Ubungo, and Kigamboni (fig. 3.02), which are also autonomous Local Government Authorities and administrative districts of the region, Mshumbusi, (2011); Kiunsi, (2013); URT, (2016a); and URT, (2016b). Population wise, Dar-es-Salaam city has been experiencing rapid population growth, hosting almost $10 \%$ of the national total population, URT, (2016a). Example, in 1988, the population of Dares-Salaam city was 1.2 million, it then increased to 2.3 million in 2002, 3.3 million in 2007, 4.3 million in $2012,4.5^{9}$ million in 2013, 5.3 million in 2016, and it projected to increase to about 13.3 million in 2036, Abebe (2011); Kiunsi, (2013); URT, (2016b); and URT, (2016a). Moreover, the projection of urban population growth rates of about $4 \%$ between 2010 and 2025, shows that; Dar-es-Salaam now is a megacity, due to its population being more than 5 million inhabitants, URT, (2016b).

Furthermore, the city has been experiencing rapid urbanization growth and development, of $4.3 \%$ from 1998 to 2002, 5.6\% from 2002 to 2012, and $4.5 \%$ in the period of 2015 to 2020 , Mbisso \& Kalugila, (2018); and Ricci, (2019). This increase, has led to the city sprawling continuously, forming a number of informal settlements which tripled from 40 in 1985 to over 150 in 2003, and are expected to increase further (fig. 3.03), due to the city being the largest seaport, industrial, commercial and administrative centre in Tanzania, Kalugila \& Mbisso, (2018); Kombe (2003) in Abebe, (2011). Additionally, Lupala \& Kiunsi (2011) in Kiunsi, (2013) highlight that; with an average population density of 24 persons per hectare, the city has a relatively low population density compared to most other large cities. However, there are some areas,

\footnotetext{
${ }^{9}$ http://www.nbs.go.tz/sensa/PDF/Census\%20General\%20Report\%20\%2029 $\% 20$ March\%202013_Combined_Final\%20for\%20Printing.pdf, accessed on March 03, 2018.
} 
especially the informal settlements near the city centre, that have densities of 300 or more persons per hectare. This is due to the fact that; only $22 \%$ is a built-up area and about half of it is estimated to an informal settlement, Kiunsi, (2013).

Fig. 3.03; the continuous urban sprawl, and projection on how it has been taking place along the road network in Dar-es-Salaam, from 2002 and how it will be by 2022 .

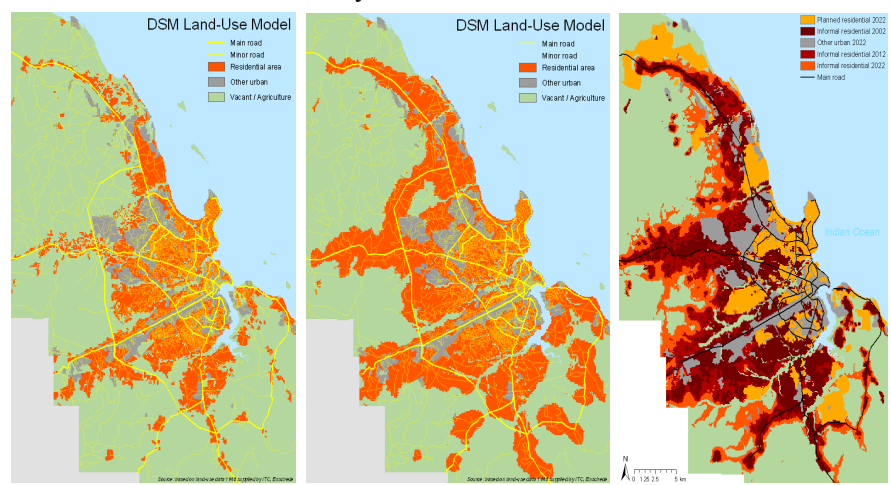

Source; Lupala, (2012) \& Kalugila, (2014).

The rapid and uncontrolled urbanization growth, is often absorbed into informal settlements, which accommodates $70 \%$ and $80 \%$ of the Dar-es-Salaam city's population, and $80 \%$ to $90 \%$ of urban residential housing stock as per Kombe \& Kreibich, (2000) in Nguluma, (2003); Kyessi \&Kyessi, (2007); Nkya \& Lupala, (2010); Makalle, et al., (2011); Mushumbusi, (2011); Bahendwa,(2013); Kiunsi,(2013); Abebe, (2011); URT, (2016); Kiondo \& Mosha, (2017); Mosha, (2017); Kalugila \& Mbisso, (2018); Mbisso \& Kalugila, (2018); Teyanga \& Mrema, (2018); and Ricci, (2019). These informal settlements, are known as squatters, or unplanned settlements, or low-income settlements, or unauthorized settlements, or uncontrolled settlements or semi-permanent settlements, or spontaneous settlements, as per Burra, (2006) in Kalugila, (2014). In Tanzania context, they defined in a number of ways, which as per UN-Habitat, (2003); Nguluma, (2003); Rasmussen, (2013); and Kikwasi \& Mbuya, (2019) includes;-

- housing areas developed outside official land development process and procedure,

- housing areas, where a group of housing units have been constructed on a land in which the occupants have no legal claim, or which they occupy illegally; or unplanned settlements are areas where housing is not in compliance with current planning and building regulations (i.e. unauthorized housing),

- an unplanned settlement on land which has not been surveyed or proclaimed as residential, consisting mainly of informal dwellings (shacks), and

- as unplanned neighborhoods comprising of a mix of middle- and low-income earners, living face to face.

For this paper; informal settlement are partially or fully unplanned neighborhood accommodating a wide range of social and economic groups of people from low- middle- and high-income earners, (predominantly the low income earners) and are developed outside the formal system, without meeting a range of regulations relating to planning, land use, and health and safety. According to Kyessi, (2000); Nguluma,(2003); Abebe, (2011); Mushumbusi, (2011); Makalle, et al., (2011); Kiunsi, (2013); URT, (2016); Mosha, (2017); Kiondo \& Mosha, (2017); Msuya, et al., (2017); Mbisso \& Kalugila, (2018); and Kikwasi \& Mbuya, (2019), apart from offering alternative affordable shelter to most poor/low-income households, they are characterized by;-

-housing constructed on lands occupied illegally, having no legal claim i.e. land lacking security of tenure, due to being acquired under informal subdivision of legally owned plots and market transaction,

-weak governance (particularly in the areas of policy, planning, land and urban management resulting in land speculation and grabbing),

-housing built under non-compliance with formal/legal building codes, planning and standards,

-land use patterns that are highly mixed, including small industries and urban agriculture,

-housing built under self-help incremental housing construction, with the intention of owner-occupation, renting out or both,

-housing built primarily with informal financing methods, i.e. family savings, capital from inheritance, sales of inherited land or savings from informal credit associations.

-poor spatial quality, public infrastructures and service provision in terms of water supply, spaghetti water connection, sanitation, solid and liquid waste management system, roads network and storm water drainage systems, blockages in natural drains, etc.,

-having rental accommodation on a room by room basis as the most common form of tenancy, as well as small and large-scale landlords,

-builders employ local building materials, skills, designs and indigenous technology, hence 
displaying diversified housing units in terms of type and construction quality, alongside structures with permanent or modern building materials co-existing with temporary or traditional ones,

-composing heterogeneous urban population,

-housing densities that normally increase rapidly up to a saturation or over-densification stage, exhibiting unique urban designs with significant variations in layouts and spatial arrangements,

-informally built houses exhibit high variations in types and quality of construction, ranging from traditional construction materials (e.g. mud and pole or thatch) to modern quality components (sand-cement blocks, concrete blocks, reinforced concrete, corrugated iron, aluminum, zinc, or tin roofs), and

-housing built as a result from the scarcity of formal land resources, long government process and delay in providing planned urban surveyed land or plots, and inefficient housing policy.

Kalugila, (2014); and Mbisso \& Kalugila, (2018), enlighten that; the informal settlements in Dar-esSalaam, apart from accommodating both the affluent and the poor, side by side, while interacting in many ways, they can be categorized in two major groups; homogeneous or heterogeneous informal settlements. They elaborate that; homogeneous informal settlements are characterized by low- or middle-income social-economic groups, while heterogeneous informal settlements, comprises both low-, middle- and high-income social-economic groups. As per Kyessi, (2002); UN-Habitat, (2010); Abebe, (2011); Mshumbusi, (2011); Bahendwa, (2013); Kiunsi, (2013); Kalugila, (2014); and Teyanga \& Mrema, (2018), their growth can be documented in three phases/stages, density and zones situated in diminishing order of proximity from the CBD, these includes;-

-Infancy, Starting, Expansion or Formation Stage; a stage at which the land available (e.g. for agricultural land use including crops such as coconuts, cashew maize), is invaded, converted and gradually cleared to allow housing construction by low- and middle-income households. It is depicted by scattered layout of built forms that are sparsely built and populated, which in time proceed from scattered expansion to reach collective expansion stage, where almost $50 \%$ of the settlements area is built-up. In most cases, the development in these low-density informal settlement is at the beginning, locate away from the city centre, i.e. in the fringe of the city, or in the peri-urban zone like; Goba, Makabe, Madale, Kibamba, Bunju, Mbagala Rangi Tatu, Yombo Dovya, Chamazi, Chanika, Somangila, Buza, Tungi, etc.

-Booming, Consolidation or Densification Stage; a stage at which land use is largely changing from agriculture to residential use, whereby immigrants from various parts, are gradually displacing the farmers. The vacant land available is subdivided into smaller portions and sold mainly for housing construction, hence attracting more, the middle income groups. Infrastructure is gradually improved by individual and community or local government authority efforts. At this stage, the land is not fully built, i.e. about $80 \%$ of the land used for housing construction. Most of such medium-density informal settlements are located in the intermediate zone i.e. at the medium distance from the city centre, like; Kimara, Changanyikeni, Makongo Juu, Mbezi, Tegeta, Tabata, Mbagala, etc. and,

-Saturation or Intensification Stage; a stage whereby additional construction is primarily entertained through vertical densification. They are normally $100 \%$ built informal settlements in the inner city, where land development pressure is high, due to high land value and demand. Horizontal expansion is often limited or restrained, so intensification is largely through vertical extension, infill and gentrification. Some have good access to basic services and some not. These high-density informal settlements, are located in the inner core zone of the city are characterized by high concentrations of both houses and people, and a number of settlements prone to floods, Manzese, Tandale, Kigogo, Msimbazi Valley, Mlalakuwa, Msasani Makangira, Msasani Bonde la Mpunga, Hanna Nassif, Kawe Ukwamani, Vingunguti, BuguruniMnyamani, Buguruni-Malapa, Keko, Tandika, etc.

In most cases, the informal settlements are located in the around the higher learning institutions (e.g. Mlalakuwa, Changanyikeni, Makongo Juu etc.); around the industrial area (e.g. Masasani-Bonde la Mpunga, Msasani-Makangira etc.); along the major reads (e.g. Tegeta, Bunju, Boko, Kimara, Kibamba etc.) and in the peri-urban (e.g. Madale, Chamazi etc.). Although informal settlements continue to grow in all direction, their greatest concentration is 
in Kinondoni District ${ }^{10}$, which is the most populous municipality in the city, comprising of half the city's population and most of its high-income residential areas, Kiunsi, (2013); and Ricci, (2019).

Fig. 3.04; the location of the study area of Mlalakuwa urban informal settlement, in Dar-es-Salaam, Tanzania.

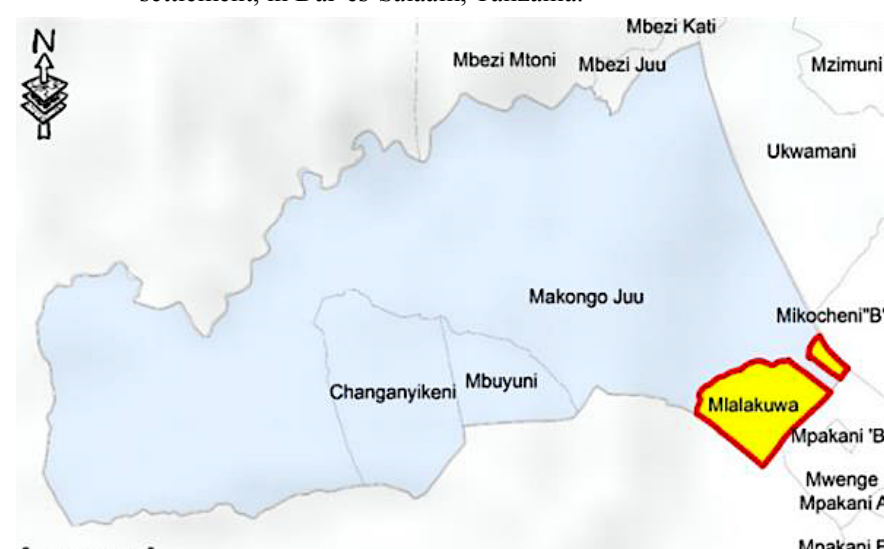

\section{Legend}

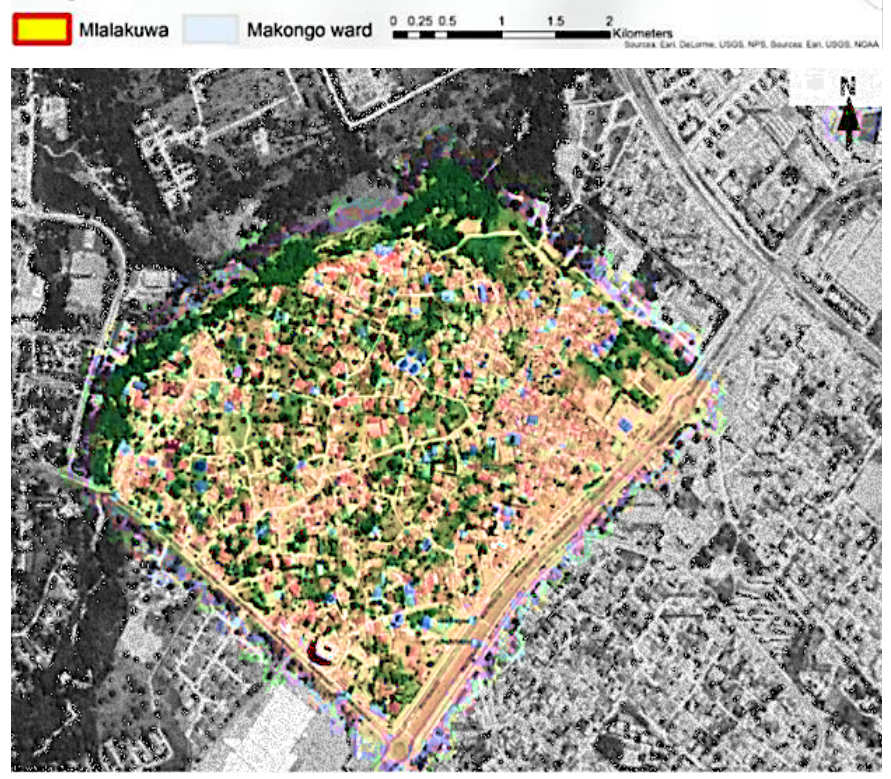

Source; Juma \& Babere, (2019) and modified by Author, (2020).

In all the informal settlements found in Kinondoni Municipality, Mlalakuwa informal settlement was selected as a case study area due to its information richness, contributed by the coexistence of heterogeneous socio-economic groups from low-, middle- and high income earners; availability of various livelihood activities (i.e. petty trading, urban agriculture and livestock keeping etc.); its location, proximity to the researcher's residence; the researcher's general familiarity with the case study area; easiness on accessibility and communication channels with local leaders (Serikali za Mtaa); being a consolidated settlement with clear

\footnotetext{
${ }^{10}$ Tanzania: Country Assessment Report. The World Bank, AFTU 1 \& 2. January 2002, (http://web.mit.edu/urbanupgrading/upgrading/caseexamples/overview-africa/country-assesments/reports/Tanzaniareport.html) accessed on April, 23,2020.
}

physical structure; economically vibrant; and being an informal settlement at the saturated or intensification stage, located in the intermediate zone from the city centre, as well as a high-density settlement in terms of population.

\subsubsection{Mlalakuwa Urban Informal Settlement}

Malalakuwa is one of the oldest prominent informal settlement and an institutional related settlement, located approximately 9.7 kilometers from the city centre, in a sub neighborhood in Makongo Ward (fig. 3.04), in Kinondoni Municipality, Dar-esSalaam City, Tanzania. It is bordered by Ardhi University (ARU) and University of Dar-es-Salaam, (UDSM-Main Campus) on the Western part; Sam Nujoma Road and Sinza Neighbourhood on the Eastern part; Bagamoyo highway, Lugalo Military Barracks, Tumaini University and Mikocheni light industrial areas on the Northern part; and Mlimani City Mall and University of Dar-es-Salaam, (UDSM-Main Campus) on the Southern part. Its name is derived from an essentially small and seasonal/temporary river, largely serving as a drainage network for Dar-es-Salaam City, especially during seasonal rainfall, Parsa, et al., (2011); URT, (2012); and URT, (2016). The settlement is bordered by three main local roads; the University Road, and Sam Nujoma and Bagamoyo highway, that provide a good linkage from the settlement to other part of the city including the city centre, Parsa, et al., (2011); Kalugila \& Mbisso, (2018).

Malalakuwa with the size of approximately 16 ha, has a population of about 19,453 people; 9950 men and 9503 women according to a Census Report of 2012, Parsa, et al., (2011); and URT, (2013). Its population continues to increase as a result of migration from different hinterland areas and natural growth, (URT, 2012); and Kalugila \& Mbisso, (2018). Kombe \& Kreibich, (2006) assert that; up to the late 1960's, the settlement was mainly a paddy cultivation area with only few scattered rural huts, built with temporary materials (i.e. mud, pole, and thatch), whereby the 1967 aerial photographs show that, there were 33 houses in Mlalakuwa, and the number of houses increased to 374 in 1982 and 1,804 in 1992 that is, a rise of about $75 \%$ in ten years. In the year 2002 already 2,513 houses accommodating 15,000 people had been built, implying an increase on the amount of space use, the number of house types and 
Dennis N.G.A.K. Tesha/Households Livelihood Coping Strategies in the Urban Informal Settlements; the Case of Mlalakuwa, Dar-es-Salaam, Tanzania.

construction done, making the settlement, a high density area. The settlement accommodates students and workers from various higher learning institutions, like Ardhi University (ARU) and University of Dar-es-Salaam (UDSM) as they are close to the area, and other non-professional and professional workers from various areas in the city.

\subsection{Data Collection and Analysis}

In-line with writing by Kumar, (2011); Kombo \& Tromp, (2014); Magigi, (2016); and Kothari, (2019); the study employed a household survey methodology, with a research design being a case study. Basing on the five capital assets, the study explored the households livelihood strategies and opportunities in informal settlements of Mlalakuwa in Dar-Es-Salaam, Tanzania. The qualitative data collection was done using multiple data collection tools (triangulation for validity and reliability purposes), via in-depth semi-structured interviews with purposively selected 114 key informants households (table 3.01) selected through stratified random probability sampling technique, reconnaissance, field observations to cover the gap between interviews, sketches of the existing situation, mapping and photographic registration, for the primary data, supported with literature review, for the secondary data. Furthermore, the empirical evidence for this paper bases from field studies conducted at Mlalakuwa informal settlement in Dar-es-Salaam city, in 2013 and 2019. The primary units of analysis were individual households. The interview questions comprised questions on demographic and socio-economic characteristics of households, livelihood activities, livelihoods strategies, and housing facilities. The collected data and information were coded and analyzed quantitatively and qualitatively, whereby descriptive statistical and content analysis were employed in data analysis, and presented in the form of text, percentages, sketches and mapping of the exiting situation, tables, and photographic impressions.

Table 3.01: the household demography and socio-economic characteristics.

\begin{tabular}{|c|c|c|c|}
\hline SN. & Characteristics & Number & Percentage \\
\hline$A$ & \multicolumn{3}{|l|}{ Households Gender } \\
\hline 01. & Male & 43 & $37.7 \%$ \\
\hline 02. & Female & 71 & $62.3 \%$ \\
\hline & Total & 114 & $100.0 \%$ \\
\hline$B$ & \multicolumn{3}{|l|}{ Households Age } \\
\hline 03. & $20-30$ years & 18 & $15.8 \%$ \\
\hline 04. & $30-40$ years & 62 & $54.4 \%$ \\
\hline 05. & $40-50$ years & 28 & $24.6 \%$ \\
\hline 06. & Above 50 years & 06 & $5.2 \%$ \\
\hline
\end{tabular}

\begin{tabular}{|c|c|c|c|}
\hline & Total & 114 & $100.0 \%$ \\
\hline $\bar{C}$ & \multicolumn{3}{|l|}{ Households Level of Education } \\
\hline 07. & Primary & 28 & $24.6 \%$ \\
\hline 08. & O-Level Secondary Education & 22 & $19.3 \%$ \\
\hline 09. & A-Level Secondary Education & 16 & $14.0 \%$ \\
\hline 10. & Vocational Education & 12 & $10.5 \%$ \\
\hline 11. & College & 10 & $8.8 \%$ \\
\hline 12. & University & 22 & $19.3 \%$ \\
\hline \multirow[t]{2}{*}{13.} & None & 04 & $3.5 \%$ \\
\hline & Total & 114 & $100.0 \%$ \\
\hline $\bar{D}$ & \multicolumn{3}{|l|}{ Households Marital Status } \\
\hline 14. & Single & 08 & $7.0 \%$ \\
\hline 15. & Married & 82 & $71.9 \%$ \\
\hline 16. & Widowed & 12 & $10.5 \%$ \\
\hline 17. & Divorced & 06 & $5.3 \%$ \\
\hline \multirow[t]{2}{*}{18.} & Co-habiting & 06 & $5.3 \%$ \\
\hline & Total & 114 & $100.0 \%$ \\
\hline $\bar{E}$ & \multicolumn{3}{|c|}{ Number of Children in a Households } \\
\hline 19. & Below 5 years & 16 & $14.0 \%$ \\
\hline 20. & $5-10$ years & 74 & $65.0 \%$ \\
\hline 21. & $10-15$ years & 16 & $14.0 \%$ \\
\hline \multirow[t]{2}{*}{22.} & Above 15 years & 08 & $7.0 \%$ \\
\hline & Total & 114 & $100.0 \%$ \\
\hline $\bar{F}$ & \multicolumn{3}{|l|}{ Households Occupational Status } \\
\hline 23. & Self-employed & 72 & $63.1 \%$ \\
\hline 24. & Formal Paid Work & 14 & $12.3 \%$ \\
\hline 25. & Unemployed & 22 & $19.3 \%$ \\
\hline \multirow[t]{2}{*}{26.} & Retired & 06 & $5.3 \%$ \\
\hline & Total & 114 & $100.0 \%$ \\
\hline
\end{tabular}

Source; Juma \& Babere, (2019) and modified by Author, (2020).

\subsection{RESULTS \& DISCUSSION}

The Tanzania's Development Vision 2025, wishes to attain a high quality of livelihood for its citizen; URT,(2010). Given the average household size of 4 to 5, (fig. 1.01), UN,(2017), the study explored various households livelihood coping strategies, in the urban informal settlement of Mlalakuwa in Dares-Salaam, Tanzania, by looking at the livelihood activities basing on the DFID sustainable livelihood framework's five assets. Basically, Mlalakuwa informal settlement has copious shapes and sizes of households, that can be differentiated by relative well-being, their access to resources and power. Its households, use their assets and capabilities to engage in several dissimilar livelihood activities, as a coping strategy (i.e. the ways of combining and using assets to achieve the livelihood diversification $^{11}$ in order to ensure their main survivor), against life stress and shocks. According to number of studies on livelihood,

\footnotetext{
${ }^{11}$ Livelihood Diversification as per Ellis, (1999); Kassa, (2019); refers to a household's attempt to reduce its vulnerability by having more than one livelihood activity. It is "the process by which households construct a diverse portfolio of activities and social support capabilities for survival and to improve their standard of living. In a diversified household, if one productive activity does not provide enough, or fails completely, there are other sources of livelihood that the household can fall back on. environment known as the vulnerability context.
} 
[.....] "the more diversification there is in the livelihood strategies of a household, the more secure it is likely to be, with a better livelihood outcomes. More desirable livelihood outcomes vary from household to household, and increased well-being is usually a high priority" - DeSatgé \& Holloway, (2002) $)^{12}$

The five livelihood assets explored with in Mlalakuwa urban informal settlements, included:-

\subsection{Human Capital (H)}

Human capital represents the capabilities; skills; creativity; education level; knowledge; security of formal employment or casual work; income earning-dependency ratio; entrepreneurial ability; person experience or ability to work(labour); safe environmental conditions; number of household members (productive, non-productive); age and gender; household conditions (family background and problems); life philosophy; and good health care; etc. that contributes on enabling households to pursue different livelihood strategies to achieve their livelihood objectives, DFID, (1999); Ellis, (1999); Farrington, et al., (2002); Rakodi \& LloydJones, (2002); and Oluwafemi, (2013); Layson, (2013); Xu, et al., (2015); Han, Ba, \& Xin, (2015); Abu-Salia, et al., (2015); UNDP, (2017); Rafea, (2017); and Kassa, (2019). At a household level, human capital is a factor, which determines the quantity and quality of available work force; this varies according to household size in terms of total number of family members, skill levels, full-time and part-time laborers within family, the highest education level obtained by family members, leadership potential and ability, health status, etc. DFID, (1999); Farrington, et al., (2002); Han, Ba, \& Xin, (2015); and Rafea, (2017). Basically, lack of skills as well as formal and informal education (i.e. learned their jobs through long time experience to work with already experienced people), affects the ability to secure a livelihood. DFID, (1999); Farrington, et al., (2002); and UNDP, (2017) insists that; financial capital, in terms of access to employment and earnings, strongly dependent on adequate human capital, which is always required in order to make use of any of the four other types of assets.

The study revealed that; $96.5 \%$ of the households interviewed in Mlalakuwa urban informal

\footnotetext{
12 De-Satgé, R., \& Holloway, A., (2002); "Learning about Livelihoods: Insights from Southern Africa, Volume 1: Insights from Southern Africa", Volume \#01, Peri-peri Publication, OXFAM, ISBN: 08-5598-4686, ISBN: 9-7808-5598-4687, 361 Pages.
}

settlements in urban areas, have the ability to read and write due to having different levels of educational skills and training (table 3.01), hence indicating their potential in terms of socio-economic and human development skills, specifically the availability of skilled and unskilled labour in the area, Moreover, it also revealed majority of the households interviewed $(63.1 \%)$ being selfemployed, and $12.3 \%$ working for someone else (i.e. with formal permanently or temporarily employment), while the remaining households being either unemployed $(19.3 \%)$ or retired $(5.3 \%)$. They are engaged in agricultural (farm) or nonagricultural (non-farm) and financial (monetary) or non-financial (non-monetary) livelihood activities, as coping strategy. The $75.4 \%$ employed households coincide with finding by Makalle, et al., (2011), as they incorporate; academicians and professional graduates from ARU, UDSM, TUMAINI, ISW, IFM, CBE, MUHAS and other colleges (i.e. architects, planners, valuers, quantity surveyors, land surveyors, engineers, economists, community social workers, lawyers, bankers, health workers e.g. doctors, pharmacist, and nurses, teachers etc.), graduates from Vocational Education Training authority (VETA) engaged in masonry work, carpentry, stationary and printing business, catering, motor vehicle mechanical garage, motor tri-cycle (rickshaw or bajaj) and motor cycle repairing, electrical and welding, vehicle driving schools, women and men salon, etc.

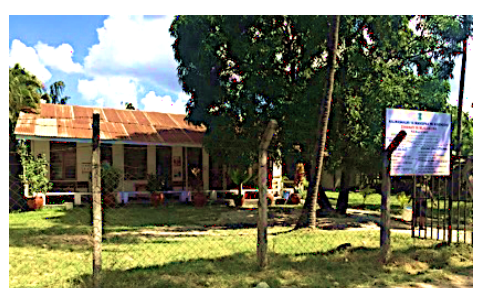

Plate 4.01; Mlalakuwa Dispensary.

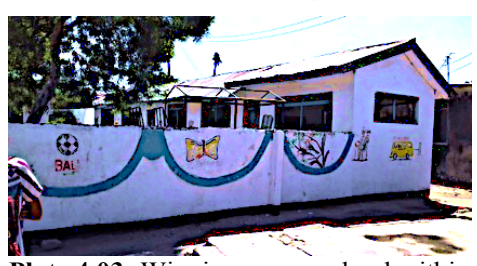

Plate 4.03; Winnie nursery school within Mlalakuwa.

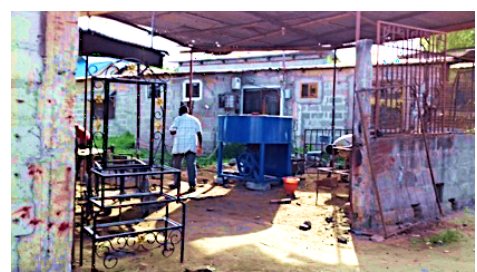

Plate 4.05; a steel welding light industry in Mlalakuwa.

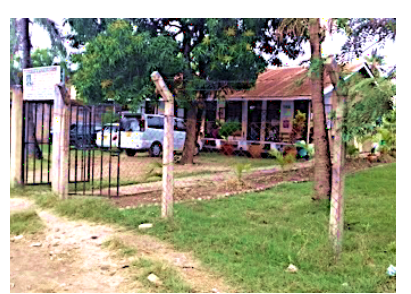

Plate 4.02; Mlalakuwa Dispensary

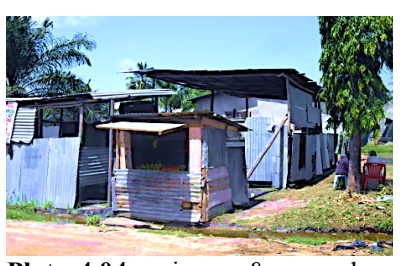

Plate 4.04; primary \& secondary school tuition centre within Mlalakuwa.

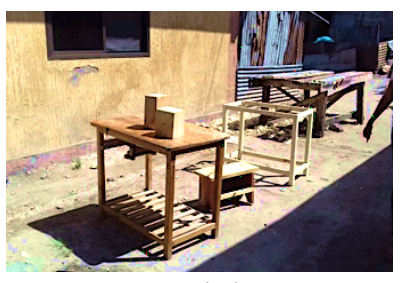

Plate 4.06; a timber carpentry light industry in Mlalakuwa 
Furthermore, the settlement has a nursery school (plate 4.03), but neither secondary nor primary school, and as a coping strategy, some high school graduates and professional teachers, who attained education in different schools and higher learning institutions outside the area, and in agreement with several head of households; they have established local tuitions for the kindergarten, primary pupils as well as ordinary and advanced level secondary students creating their own self-employment or an extra-curricular income generating activity for those with formal employment, to attain Financial Capital, against life stress and shocks. The households also receive health care and medical services from Lugalo Military Hospitals, one $(01)$ public dispensaries(plate 4.01 and 4.02), and nine(09) pharmaceutical shops in the areas, (table 4.01); which is in-line with the goal 03 on ensuring good healthy lives and promoting well-being for all at all ages, of the sustainable development goals ${ }^{13}$. Findings tally with DFID, (1999); Ellis, (1999); UNDP, (2017); Fang, et al., (2014); and Xu, et al., (2015) that; availability of formal education and training centers, as well as good health and medical care, which develop the knowledge and skills, sharpens the health and quality of the available human capital, play a substantial influence on the choice of livelihood coping strategy, as well as increasing the number of labour force, hence leading to better productivity, and as a result a gain in Financial Capital. A respondent reported that;-

[...... "as you can see, we live very close to Mlalakuwa Dispensary, owned by the government, that is where everyone in my household go whenever one feels abnormal or sick, and if it so serous we opt for the Lugalo Military Hospital. With regards to education, I have four children, two have graduated university, one is in form four, and another is in form two, the two in secondary school, whenever they come back for holiday, they attend the available tuition centers, you see near the health centre. They are cheap, and flexible in terms of payment, with highly qualified form six graduate from prominent school, and teacher from different areas" - a head of the households.

A study by Rafea, (2017), also revealed the same finding as in Mlalakuwa informal settlements, whereby; formal employed teachers who depend on private lessons as a strategy to increase their income, with parents insisting on how their children gain more by attending the private lessons, alongside keeping them busy and away from joining and groups with bad influence. The study also

${ }^{13} \mathrm{https}: / /$ www.un.org/sustainabledevelopment/sustainable-development-goals/ 6059

The International Journal of Social Sciences and Humanities Invention, vol. 7, Issue 07, July 2020 revealed an existing of informal education which offers theoretical and practical skills, that has increased individual's productivity by enhancing their innovation, creativity and ability to absorb new technologies, in various livelihood activities, such as welding, carpentry (plate 4.05 and 4.06), masonry, female and male salon, tailoring, food vending, retail and shop keeping, printing and stationery business, mechanical in garages for cars, motor tri-cycle (rickshaw or bajaj) and motor cycle, etc. Example, one respondent detailed that;-

[...... "when I finished form four education in the village, I requested my late uncle who was welder, to join his staffs, and teach me, how to weld different things, I started learning how to weld windows, gates for the doors, balustrades, beds, and curtain accessories. When he passed away in 2010 due to accident, three years and eight months after I had joined him, I requested my aunt to inherit his business and tool, so that I would continue to support our family, his and mine in the village. Since then, almost nine years, I have been here, and we are now six people including my young brother who joined this year", - a welder in the settlement.

The study also revealed that; $68 \%$ of the respondent's households size, had between 8 and 12 people, with most of them (93\%) being dependents of the age less than 15 years, hence increasing the vulnerability likelihood to socioeconomics financial stress and shock. The average household size as per Oluwafemi, (2013); and Fang, et al., (2014); UN,(2017) is between 4 to5 persons (fig. 1.01), which is less that what was found in Mlalakuwa informal settlement. Thus, the households number reflected in the findings, reflects writings by $\mathrm{Xu}$, et al., (2015) that; the larger the family size is, the greater the daily consumption will be; thus, the heavier the burden on the head of the households, forcing the exploration of more than one livelihood coping strategies

\subsection{Physical Capital (P)}

Physical capital comprises of assets such as housing; production tools, equipment (machinery) and properties (e.g. land, housing, agricultural equipment, sewing machines, ) that people own, rent or use; the basic public infrastructure (e.g. access roads, transport, water supply, energy, ICT and communication, hospitals) and provision of public services (access to health care, education, electricity, sanitation systems, garbage collection, access to assistance and crime protection) that can be accessed; as well as food stocks, jewelry, household assets, and livestock; and other means 
that enable people to pursue livelihoods, DFID, (1999); Ellis, (1999); Rakodi \& Lloyd-Jones, (2002); Makalle, et al., (2011); Eneyew \& Bekele, (2012); De-Haan, (2012); Layson, (2013); Rafea, (2017); UNDP, (2017); and Davidson et al., (2014) in Kassa, (2019).

The study revealed the components of basic public infrastructure within the Mlalakuwa urban informal settlement to be inadequate despite having better access to information (communication), electric supply, health care and medical services, etc. The inadequacy was due to; poor, narrow and untarmacked road network which inhibit transportation within the settlement, lack of street lights, poor water supply and spaghetti connection, poor solid waste management systems, lack of clean energy as some households used charcoal and firewood in their heating activities, lack of drainage and sanitation system, poor housing condition in most households, etc. In order for households to attain sustainable livelihood, all these essential components for basic public infrastructures must be adequate, as per DFID, (1999); and UNDP, (2017).

Fig. 4.01: the existing building skyline and infrastructures (i.e. road network, drainage etc.), within Mlalakuwa urban informal settlements.

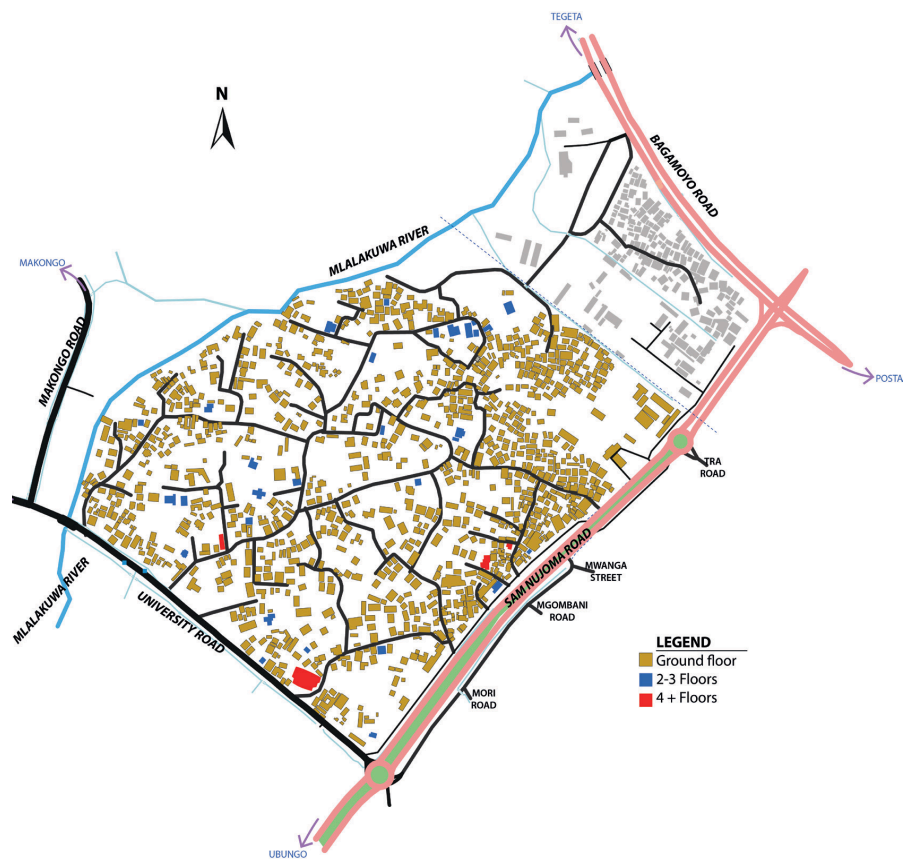

Besides, households in Mlalakuwa, were found to have three indicators used in quantifying physical capital as per $\mathrm{Xu}$, et al., (2015), which included the present value of the physical home; the present value of the household fixed assets (i.e. water pump, cattle, bicycle, motorcycle, motor tricycle, car, television, refrigerator, washing machine, mobile cell phone, air conditioning, water heater, modular furniture, computer, etc.); and the household location (i.e. distance from the household to the city center). The fixed assets had a significant influence on the households livelihood coping strategy, contrary to $\mathrm{Xu}$, et al., (2015) findings.

The influence of fixed asset on livelihood is exhibited by $11 \%$ of the households interviewed, who own electrical pumps operating private underground and elevated portable water reservoir from water supplied by DAWASA, where their wives have secured a self-employment by selling a bucket of water at TZS 100/= (financial capital) to their tenants, and other neighbouring households. The settlements was also observed to constitute of carpentry and masonry activities where residents use their own electrical and manual machine to operate in making sand-cement blocks, welding various housing elements, such as doors, windows, gates, stairs, furniture etc. for selling. A respondent evidenced that;-

[...... "My wife sells water supplies by DAWASA, one bucket for TZS 100/= (i.e 0.043U\$D), and she normally ends up with a profit of 120,000/= (i.e 51.87U\$D), after deducting all running costs including water and electrical bill. We use the profit for paying school fees, buying food supplies, buying building materials as you can see we have been extending our house for renting to the university students, etc." - head of the household.

Majority of housing types (fig. 4.01) in Mlalakuwa, are under insecure tenure, despite playing a key role in contributing households livelihood coping strategy. The is due to the fact that; some head of the households, have rented the whole house to tenants or transformed their houses incrementally (fig. 4.02), by adding room by room (i.e. extension) for renting different rooms (financial capital). The transformation, which also adds income from rent and the estimated value of the house; is done by local fundi's ${ }^{14}$ and artisans, using sand-cement blocks, aluminum industrial trough (I.T.) and corrugated iron sheet as roofing materials, concrete, as building materials, which is in-line with writing by Rakodi and Lloyd-Jones, (2002); Han, Ba, \&

\footnotetext{
4 "Fundi's or Mafundi" are the main actors in the process of housing construction in the informal settlement like Mlalakuwa, as "self-educated architects" who have been playing the role of a formally trained architects and engineers in the informal settlements, thus using their skills to create self-employment (Human Capital) and attain Financial Capital, Nguluma (2006). Moreover, they play an active role in supporting housing construction and transformation taking place particularly in low-income informal settlements as households tries to utilize their Natural Capital to gain Financial Capital via renting activities as well as becoming shock absorbers to the extended family/relatives, Nguluma (2006).
} 
Xin, (2015); and Bhattacharjee, (2016) who too reports on the same, as well as houses being used as a location for home-based enterprise, which was also the case observed, in houses rented to host retail shops, workshops, butchery, saloon etc.

Fig 4.02: diverse incremental extension by the households for renting purposes, whereby single room are transformed into single banked houses then into double banked with clerestory, mono-pitch or gable roof style.

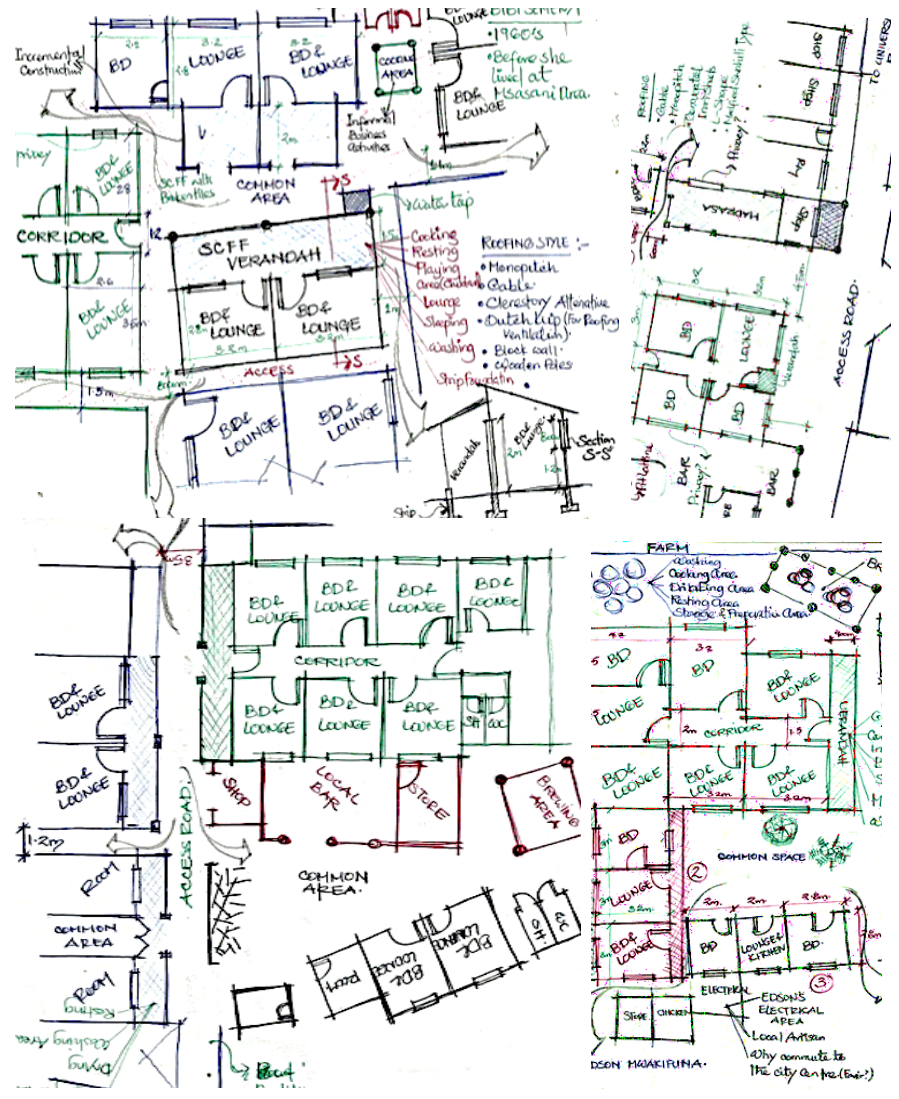

Almost all of the households in fig. 4.02, started as a single room, which were extended or tranformed incrementary room by room, as revealed in a study by Nguluma, (2003), into a full residential house.

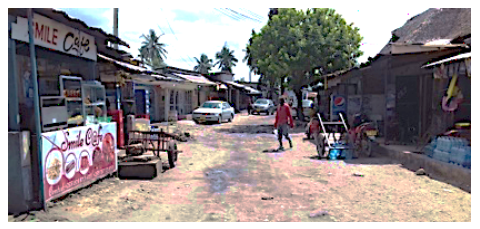

Plate 4.07; streets in Mlalakuwa informal settlement, and infrastructure status.

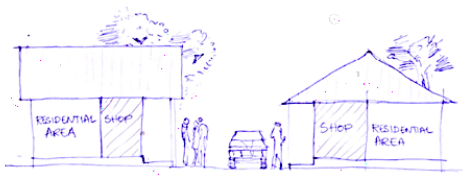

Plate 4.09; Mlalakuwa's street section on the transformation and rental.

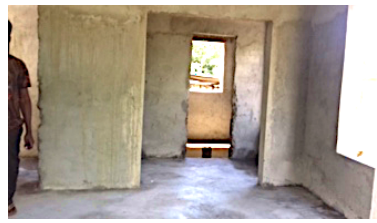

Plate 4.08; Housing extension for rental purposes in Mlalakuwa.

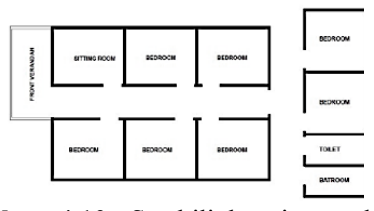

Plate 4.10; Swahili housing and its transformation and rental.
Moreover, $73.5 \%$ of the households interviewed are rent paying tenants, to the house typologies that are designed or expanded (transformed) (plate 4.08, 4.09 and 4.10), so that their rooms can accommodate, different families, students, shops and other trading facilities along the major and access roads, for the purpose of generating income via paid rents. This concur with findings by Moser, (1998) in Farrington, (2002); and Moser, (2007) in Oluwafemi, (2013) that; in urban areas, housing is one of the most important physical assets for poor urban households as it is used both for shelter and reproductive purposes, and for productive or income-generating purposes (renting out rooms or using the space as a workshop area), to ease the stress and shocks on finances. One respondent, detailed that;-

[.....] "This land was owned by my grandfather as a farm, when he passed away, my father inherited it with an existing house made of poles and mud, which he started to re-build a room by room into a sand-cement house with corrugated iron sheet roof. It was a house that I and my five sisters were born in. By the time he passed away I inherited it with the three extra room that he was renting, two to university students and one to different tenants. I have then, made more extension, as you can see, with addition of eight room, making a total of eleven room, and they are all rented by the students, (4 from ARU, 3 from UDSM, 2 from TUMAINI, 2 graduates from UDSM \& ARU). They each pay me TZS 90,000/= (i.e 38.90U\$D), a month as a rent, which I use in supporting my family, as you can see am an old man, with no more energy to do heavy activities" - head of the household.

Despite the observation on the presence of formal housing (in terms of construction materials and types), as also revealed in a study by Mbisso \& Kalugila, (2018); in Mlalakuwa, $84 \%$ of the households interviewed, acts as shocker absorbers, as they host their close relatives, and fellow students in their houses. In some other areas, the level of the squatting at household's level is even beyond the standard size of occupants per room, as per URT, (2008) in Makoba, (2008) due to overcrowdings. (Herbert, 1999; De-Soto, 2000 \& Payne, 2003) in Parsa, et al., (2011) report that; millions of households living in informal settlements in developing countries, own properties which are not recognized, hence termed as 'dead capital', due to not having adequate formal property rights that, can be used as collateral to raise cash, or in other ways transform the assets into productive capital. The same scenario was also observed in Mlalakuwa urban informal settlement, whereby households own land parcels that are not formalized, hence inhibiting them to exercise their 
property rights to attain security of tenure. These property rights, includes:-

- Rights to occupy and use,

- Rights to dispose or inherit/transfer,

- Rights to sublet, realize benefits (financial gains) or mortgage,

- Rights to develop or improve/maintain,

- Rights to restrict others from entry i.e. exclude others, and

- Rights to access services.

Furthermore, $2.6 \%$ of the interviewed households, are renting a land parcel to mobile telecommunication companies, e.g. VODACOM for the construction of telecommunication towers, and to retail shop, local bars, as well as local restaurants owners, which enables them to collect monthly land rent. The study also revealed lack of security within the areas, as $31 \%$ of the interviewed households, reported on being aware on students being robbed of their properties and belongings, especially during night times when coming from the evening studies, at a nearby higher learning institutions, or when sleeping at night in their rented rooms, by mostly pick pocketing through the windows. It was observed that; the settlement lacks a police station, which leave the residents depending on either the UDSM Police station which is almost 4 kilometers from the settlement, or Mwenge Mini-Police Station which is 1.5 kilometers from the settlement.

\subsection{Social Capital (S)}

Social capital is one of the key assets for the urban poor, which refers to the quantity and quality of social assets (i.e. social stratification and hierarchy (vertical e.g. patrons or clients); social contacts; formal and informal social networks (horizontally) built by individuals with shared interest; membership in community-based social groups; associations to which people belong; relationships and level of trust, reciprocity, kindred, inherited habits, rules, sanctions as well as shared ethical value, norms and traditions that facilitate cooperation and economic opportunities; ability to work together and expand the access to wider institutions such as political or civic bodies; access to and source of information and communication; social support and mutual or common accepted aid within communities; and assistance to or from extended family networks in rural areas, urban areas or overseas) upon which people draw in pursuit of livelihoods objectives, for example, loans, childcare, food, accommodation and information about employment and opportunities, DFID, (1999); Ellis, (1999); Rakodi and Lloyd-Jones, (2002); Dersham \&Gzirishvili, (1998) in Farrington, (2002); Limbumba, (2010); Makalle, et al., (2011); Eneyew \& Bekele, (2012); De-Haan, (2012); Layson, (2013); Putnam, (1993) in Oluwafemi, (2013); Xu, et al., (2015); Han, Ba \& Xin, (2015); Abu-Salia, et al., (2015); Moser, (1998) in Rafea, (2017); (Bourdieu, 1986; Fukuyama, 1995; Coleman, 1998; Putman, 2000; \& Woolcock, 2000) in Endris, et al., (2017); and Kassa, (2019). It is also referred as the terms of exchange between different kinds of capital, UNDP, (2017). Basically, households use these assets to reduce risks, access services, protect themselves from deprivation, and to acquire information to lower transaction costs.

The study revealed that; $48 \%$ of the households interviewed, do purchase food supplies such as rise, cooking oil, beans, sugar, baking flour, all kind of meats and seafood, from retail shops and butchery within the areas, on credit. One respondents detailed that;-

[...... "I am a taxi driver, and my wife is the secretary by professional, and as you can see despite the shop located in our frame, that we have rented it, for TZS $75,000 /=$ (i.e 32.42U\$D), a month, we are surrounded by the male salon (babershops) and female salon (beauty salon), a bar, a butchery, other shops, those selling chips "mayai"(i.e. eggs) etc.. I can't lie, they have been helpful in our daily life, example from the available agreement and trust built with owners; we pay our bills at the shop every month instead of paying whenever we got for buying our needs. Sometimes we even don't have money, we get beef (meet-cow), fish, pork or chicken from the butcher, and pay in the later days, its life", - a taxi driver and residence within Mlalakuwa informal settlements.

The result indicated how within Mlalakuwa informal settlement, social network enhance the payment mode in most aspects, e.g. retails shops, tuition centers, food and livestock products from the practiced urban agriculture, shops, male and female saloons, butchery, bar and pubs, car wash, tailoring etc. assenting with finding by Putnam, (1993) in Farrington, et al., (2002) \& All-Kamal, (2013). Besides, $51 \%$ of the households interviewed, showed how strong social network and trust, does act as a shock absorber, by revealing that; within Mlalakuwa, formal and informal employed women willingly leave their children, money and keys with neighbours, when at work, with arrangements between neighbours in-terms of feeding and taking care of the children. They clearly revealed 
willingness and trust to leave their children, money and keys is limited to only to relatives and close friends, and not just anyone in the settlement. According to one respondents, when asked;-

[.....] "My husband despite working with my neighbor, they grew together, and went to primary and secondary school together, they are also playing in the same Veteran Football Team, alongside knowing each other for the past almost 30 years. Through their closeness, I have also been so close with my husband friend's wife. We cook together in the evening and weekends, we understand and trust each other, they know us and we know them in-depth, thus, making it easier to leave my two young children, keys and even money to buy some food supplies from the food hawkers selling fish and sardines from ferry, whenever I go to work, as my friend is a stay home mother, owning this small stationery we are standing in front of', - a wife to the head of the households.

The findings relate with a study by Ellis, (2000); Oluwafemi, (2013); Bengtsson \& Klerfelt, (2014), and Busaeri, et al., (2015), which apart from higher social relations, willingness, trust and family ties revealed; they also reported on how residence in the same place, are highly involved greeting and chatting with other or among neighbours, shares the same meals, and make joint or coordinated decisions over resource allocation and income pooling. Further, $15 \%$ of the households interviewed, unveiled their appreciation on the social network they have among, and within the "bodaboda" (i.e. motorcycles) and "bajaj or rickshaw" (i.e. motor tri-cycle) associations, which has helped them in accessing self-employment, within the Mlalakuwa informal settlement. This showed how family members, depend on each other to meet end needs, by a respondents enlightening that;-

[..... "when I came to Dar-es-Salaam from Iringa in 2013, I firstly worked as an assistant daladala (i.e. bus public transport) conductor, and I lived at Mlalakuwa by then with my friend who is also from my village, and had a bodaboda owned by Mangi (while pointing the exact shop nearby). When Mangi was about to add a second bodaboda, he asked my friend to search for him a good and trustworthy driver, and I requested him if he could suggest me, of course by then he had already taught me how to drive, and sometimes I would do a night shift using his bodaboda, in order to earn more, which also made me a member of their association, in order to be able to operate at night on their "kijiwe" (i.e. designated spot or their stand where they pack bodaboda, while awaiting for customers). As you can see we are almost 15, by then when I came they were 8, the added ones are either trustworthy kin or friends from the same area, which joined us through knowing members, I also have my friend from the mosque, who gave me two motorcycles to operate for him, that are driven one by my cousin, and another one by my landlord's son", - a motor cycle "bodaboda" driver.

The study, through social ties within the community members, also revealed the availability of voluntary women organization and community-based social saving groups, where $33 \%$ of the households interviewed (mostly for women), are members who have invested these groups; hence, benefiting with mutual financial loan, that reduced their distress and sustain their life against poverty, by increasing their income and rates of saving (financial capital), a fact which was also divulged in studies by DFID, (1999); Ellis, (1999); and Nikuze, et al., (2013); and Busaeri, et al., (2015). The mutual loan given by the groups, assists the members on investing on a number of livelihood activities, for more financial gain purposes. Through community social ties enhancing their life via assisting each other in times of funeral, send-off or wedding ceremonies by either contributing e.g. fund, food products and cooking skills, borrowing of different things from each other, man power in-terms of collection of tools and preparations, cooking, decorating etc., sound system, temporary shelter, spaces, etc.; the groups also finance the funeral, send-off or wedding ceremonies via mutual loans. According to one respondent;-

[.....] "Basically, we have our women organization, that has thirty two(32) members, we started forty three(43), two(02) are deceased, and the rest nine(09) had their membership evoked either due to nonattendance to meetings, re-locating to another region, and non-payment of monthly subscription as per the rules and procedures we have. Our group has an act and a bank account, we contribute every month, for the purposes of helping each as a loan, in times of needs, such as school fees, student school upkeep, during funerals, weddings, and other various individual investments", - a member in community-based social saving group.

Additionally, the study revealed the existence of more than four (4) community-based social saving groups, accommodating various member, educated and non-educated with both formal and informal skills. Furthermore, $18 \%$ of the households interviewed, appreciated the efforts of the well-off neighbours who from time to time, do privately lend them and their kin money, as a loan, depending on the nature of strength of the social network; specifically for either school fees, feeding their 
families, paying other loans, businesses etc. A respondent, underlined that;-

[...... "I remember in 2016, months after I had lost my job, while in search of another, my neighbor, from the house with green roof (pointing at a modern single storey residential building), lecturer at "Mlimani" (i.e.. University of Dar-es-Salaam), used to lend me money all the time, and sometimes he would bring food supplies from his farm, sell some to me, and some he would give me for free, ever since I got a new job, I have paid almost $90 \%$ of the debt. I have no pressure in paying quickly, as he told, I should pay whenever I think I have enough to continue feeding my family", - a motor tri-cycle "Bajaj or rickshaw" driver.

Likewise, borrowing mechanism, is an important coping strategy that dealing with shock experienced in their life, within the area. $57 \%$ of the households interviewed, revealed kinship network as a coping strategy, which offers support to among relatives to relatives during difficult times, in terms of financial and non-financial borrowing, as it was in a study by All-Kamal, (2013) in Bangladesh, India. This finding reinforces writings by Beall \& Kanji, (1999)which also revealed that; loaning grain and cash from neighbors and relatives as diversified livelihoods strategy pattern. Livelihoods are understood not only in terms of income earning, but a much wider range of activities, such as gaining and retaining access to resources and opportunities, dealing with risk, negotiating social relationships within the household and managing social networks and institutions within communities and the city, Cephas \& Bernard, (2012).

Fig; 4.03: the existing urban agricultural activities and livestock keeping within Mlalakuwa urban informal settlements.

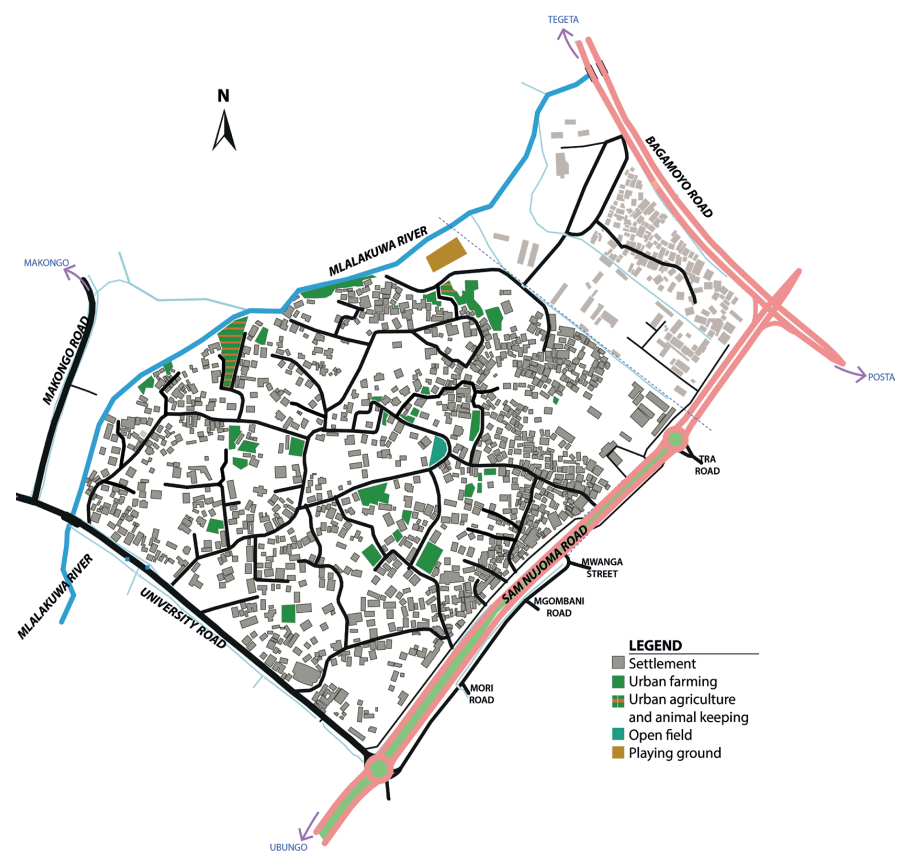

\subsection{Natural Capital (N)}

Natural capital is a stock of natural assets, which includes; all the types of developed, undeveloped and abandoned land owned by family members, water, air, livestock, fisheries, forests, wildlife, pastures, orchard, pond, as well as minerals, DFID, (1999); Ellis, (1999); Farrington, et al., (2002); Rakodi \& Lloyd-Jones, (2002); Makalle, et al., (2011); De-Haan, (2012); Eneyew \& Bekele, (2012); Layson, (2013); Han, Ba \& Xin, (2015); Busaeri, et al., (2015); UNDP, (2017); and Kassa, (2019). According to $\mathrm{Xu}$, et al., (2015), land is the most important natural capital which ensure basic existence and ultimate guarantee for stable livelihood, via housing construction, land rent, agriculture and livestock keeping, sand as a constriction material, accessibility in-terms of road network, etc.

The study revealed that; $25.4 \%$ of the households interviewed are involved in urban agricultural and livestock keeping activities (fig. 4.03) (plate 4.11 to 4.16), next to their houses, and along Mlalakuwa river, for household consumption and income generation purposes, coinciding with studies by Ojong, (2011); Fang, et al., (2014); Busaeri, et al., (2015); Bhattacharjee, (2016); and Kalugila \& Mbisso, (2018). The urban agricultural products include fresh vegetables like spinach, tomato, Chinese cabbage, etc.; fresh fruits such as, bananas, pawpaws, coconuts etc.; other green beans, maize, cassava, sweet potatoes, while the animal zero grazing activities involve; chicken, cows, goats, pigs etc. which provides meat, eggs, milk, etc. These products are also sold to the low-, middle-, and high-income earners living within Mlalakuwa. According to URT, (2016) Kinondoni Municipality, has approximately $60 \%$ of the available arable land, under cultivation; with locally grown urban agriculture providing approximately $7 \%$ of total food requirements, and 34\%of livestock needs. One respondent, reported that;-

[.....] "I normally wake up early in the morning around 6:00am, specifically to water my garden which as you can see, has a variety of vegetables (mchicha, spinach and pepper ("pilipili mbuzi")), and banana trees ("migomba"). Truly speaking, it is not easy, it is tedious, but I have to do it in order to earn money, as my kids have to go to school. By 8:00am, am always done, of course it depends if I have a customer who want to buy whatever I have during the day, otherwise I go back home do some cleaning and washing in my 
house, before I open a small women salon (beauty salon) that we use together with my neigbours to braid hair and get some money. Am sure you saw it beside the entrance of my backyard, together with two other frames that are rented one by the stationery owner, and the other by the shopkeeper. We normally open the salon around 9:30am" - farm owner, land lord and a resident in the study area.

Another one added that;-

[.....] "in life, everyone must have an alternative, and if possible alternatives, so that when you don't have a job, you are able to continue providing for your family.

Thus, when I married my wife, my household size started increasing in numbers from 3 to 8 , and now we are 11 when you add my three children, because kin schooling and working in Dar-es-Salaam see my house, as their home in this city. Hence we agreed with my wife to start a chicken business, with a support of my friend and neighbour who lives in the same area, owning a daily milling machines. Since then we have developed to having 530 chicken from 280 we started with, and two milk-cow. We sell one tray of eggs at TZS $6,000 /=$ (i.e. 2.59U\$D), in a day we collect roughly 14 to 16 trays of eggs, and when the chickens are old, not laying eggs anymore, we sell one between TSZ 8,500/= (i.e. 3.67USD) to $T Z S \quad 10,000 /=$ (i.e. 4.32USD) depending on the size. But we also supply milk to our neigbours, one liter for TZS 2,000/= (i.e 0.86USD)", a lawyer and head of household practicing zero grazing.

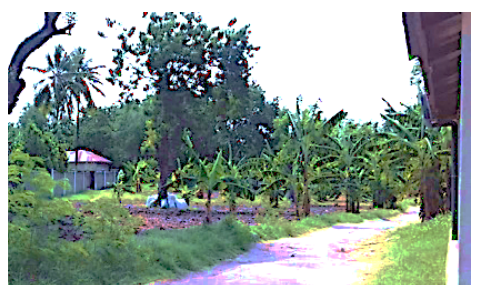

Plate 4.11; urban agriculture - the banana farming within Mlalakuwa.

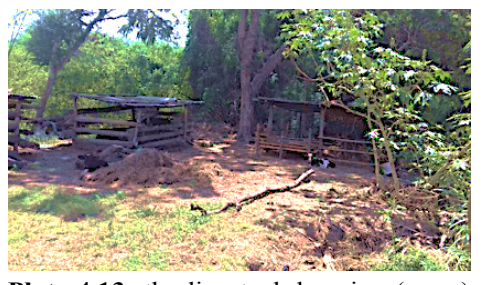

Plate 4.13; the livestock keeping (cows) within the Mlalakuwa.

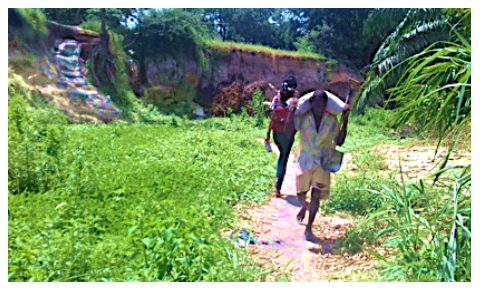

Plate 4.15; sand mining in the Mlalakuwa river.

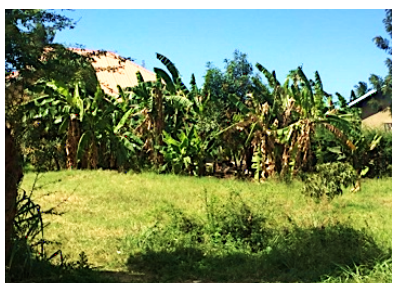

Plate 4.12; urban agriculture-the banana farming in Mlalakuwa.

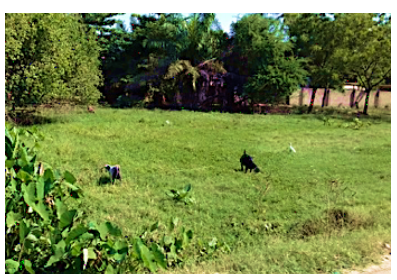

Plate 4.14; the livestock keeping (goats) within Mlalakuwa.

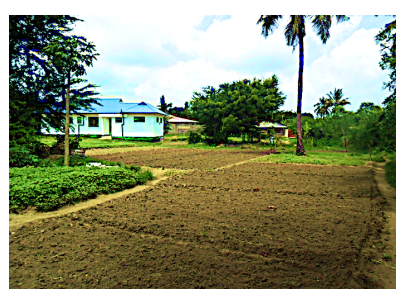

Plate 4.16; urban agriculturefresh vegetable farms in Mlalakuwa.
The findings revealed among the households involved in urban agriculture, $28.3 \%$ are male while
$71.7 \%$ are female. This shows that; urban agriculture within Mlalakuwa informal settlement, is dominated by women, who are self-employing themselves, hence having flexibility in doing multiple socio-economics activities, given the availability of land parcel, and farming being one of the investment that demands low capital. They are involved in cultivation of variety of crops on a continuous basis, despite the scarcity of land, that inhibit extensive farming; not only to increase the income generated, but also to ensure a regular flow of income, coinciding with findings by Ojong, (2011). One respondent explained that:-

[.....] "We plant maize and beans, and when the season is over, we revert to vegetables such as carrots, spinach, "mchicha”, pepper ("pilipili mbuzi”) and a little bit of tomatoes, whereby we sell $60 \%$ and retain the rest for domestic consumption. I also have eight pawpaw trees and some few banana trees ("migomba"), that I occasionally harvest and sell some, alongside consuming the remaining with my family. The money we get, some goes on saving via "VICOBA" for children education purpose, some we use it to buy salt, oil, kerosene, charcoal etc. for my household consumption", - farm owner, land lord and a residence in the study area.

Moreover, $15.8 \%$ of the interviewed households, revealed to have used firewood obtained in the area, in cooking activities during ceremonies like weddings and funerals, commercial activities for food vendors "mama ntilie", and local brewing (plate 4.17 to 4.19). The local brewing facility, "Makondeko kwa Kidevu Club", a family business, operated by a mother, sons and daughter grown, all above 30 years. The siblings have been feeding their families through the same business, paying school fees, medication during sickness, etc. It was also revealed that, the firewood is more used in the said activities, as a replacement in coping with of high electric bills and price of gas. The local brew, which is known as "komoni" is made from the dried maize and millet (plate 4.19), and it is sold to the residents within and from outside Mlalakuwa urban informal settlement.

[.....] "Komoni is a local brewer, it is our family business. It helps us to sustain our basic needs, but the income is too little for further development" - a family member.

Besides, it was also observed that; residents in Mlalakuwa informal settlement, utilize the seasonal river along Mlalakuwa in different ways. Firstly, water from Mlalakuwa river is used for irrigation purposes, for those practicing urban agriculture 
along the river area, and secondly; during heavy rainfall, the river water depth tend to increase while moving in high speed, to the extent that after rainfall and when the water depth is low, a lot of sand is accumulated thus; in coping against life shocks and stress, they collect the sand and pack it into bags (plate 4.15) either for selling or for construction purposes, e.g. mortar, sand-cement blocks (plate 4.20)., concrete, etc. One respondents said;-

[...... "Mlalakuwa river, helps us so much, we get water for irrigating vegetables as well as sand for building or extending our houses" - a head of the household.

Another respondents, shared the same by saying;-

[...... "When we want to build a house or expand our house, we just get one of our friend go to the river for sand, especially during rainy season, for making sandcement blocks which we use progressively to build a house" - a head of the household.

Findings, also revealed that; most land was attained via buying, inheritance, and land renting (tenants) for business purposes e.g. bar, car wash, garage, workshops, fast food restaurants, etc. One respondent reported that;-

[.....] "the space you see as it is, is a large one, it has a counter which also host a store, a changing room and one self-bedroom; two kitchens - one for normal food and barbeque, and another one on the other side it's for the pork meat "kitimoto"; a sitting space where we have people drinking, and most time during local and international football matches, we use it for match broadcasting; parking and toilets; and few banana trees that were originally here when we started renting this space", - owner of the local bar.

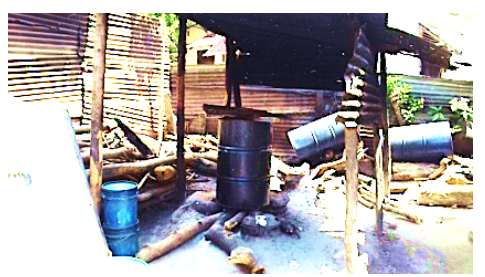

Plate 4.17; the use of firewood in cooking and local brewing activities within Mlalakuwa.

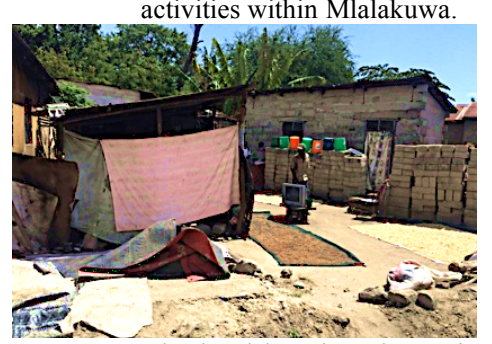

Plate 4.19; the local brewing "komoni" material drying and preparations in Mlalakuwa.

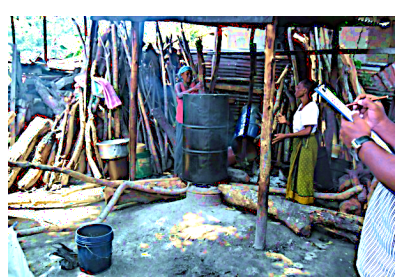

Plate 4.18; the use of firewood in cooking and local brewing activities within Mlalakuwa.

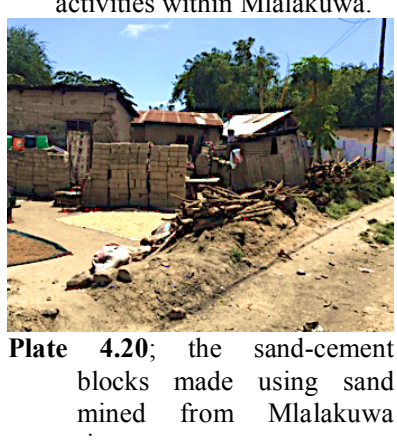
river.
Another respondent added that;-

[.....] "for this particular car wash we have an agreement between the Kinondoni Municipal council and the DDC, whereby we pay monthly rent which I cannot disclose, and the water bill to DAWASCO. Most of our customers are from the DDC Bar and Mlimani City", - owner of the car wash.

\subsection{Financial Capital (F)}

Financial capital, refers to the available financial resources, which households employ to achieve different livelihood objectives, UNDP, (2017). These include; reliable income sources such as wages/salaries, jewelry, crop or livestock sales, rent, payment or settlement or fees, savings, pensions, substitutes like cattle, groceries, etc., access to loans or credit facilities, free assistance obtained from both formal and informal channels, such as grants, aid and/or subsidies from government/non-profit organizations, remittances from family members working outside the home, DFID, (1999); Ellis, (1999); Rakodi \& Lloyd-Jones, (2002); Eneyew \& Bekele, (2012); De-Haan, (2012); Oluwafemi, (2013); Xu, et al., (2015); Abu-Salia, et al., (2015); Han, Ba \& Xin, (2015); UNDP, (2017); and Kassa, (2019). It can be understood in terms of "income from the sale of skills and labor", Twigg \& Bhat, (1998) in Farrington (2002); Rafea, (2017).

Fig; 4.04: the existing building use within Mlalakuwa urban informal settlements.

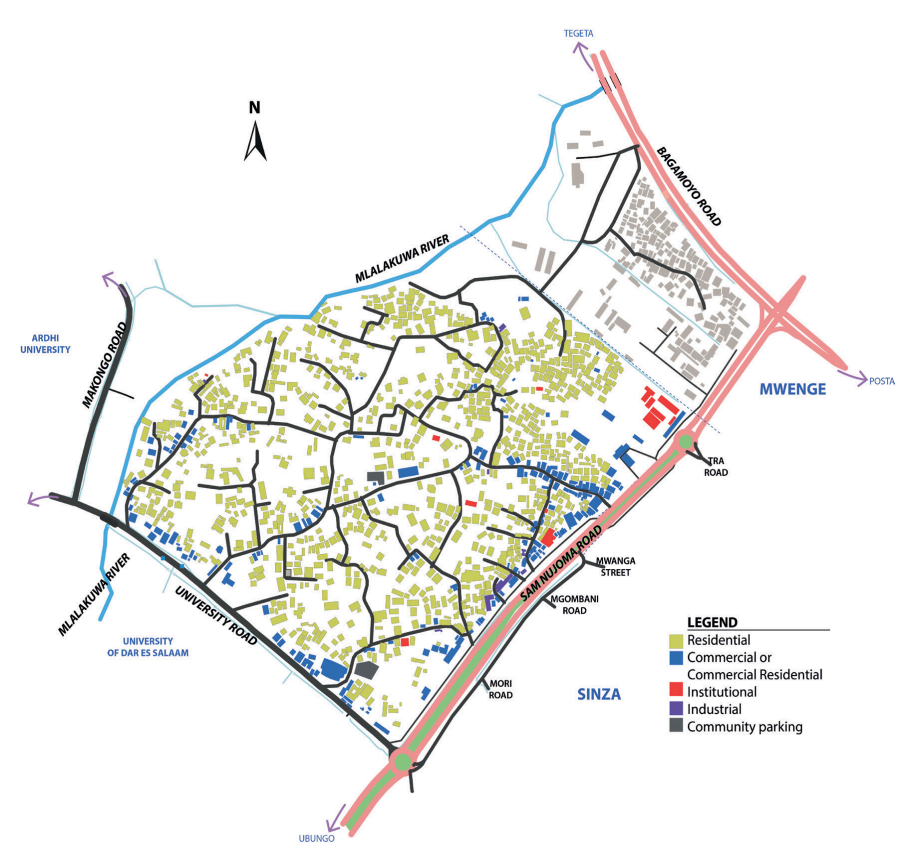

The study revealed that; $99.1 \%$ of the households interviewed are involved in several income generating activities (table 4.01), (fig. 4.03), (plate 
Dennis N.G.A.K. Tesha/Households Livelihood Coping Strategies in the Urban Informal Settlements; the Case of Mlalakuwa, Dar-es-Salaam, Tanzania.

Table 4.01. Type and distribution of commercial activities within the Mlalakuwa Urban Informal Settlement.

\begin{tabular}{|c|c|c|c|}
\hline $\begin{array}{l}\text { Commercial } \\
\text { Facility } \\
\end{array}$ & Type of Goods & Location of Trade & Number \\
\hline \multirow[t]{16}{*}{ Shops } & \multirow[t]{3}{*}{ Pharmacy } & Along the Sam Nujoma Road & 1 \\
\hline & & Along the Bagamoyo Road & 2 \\
\hline & & Along the access road & 6 \\
\hline & Cosmetics & Along the access road & 4 \\
\hline & Bakery & Along the access road & 2 \\
\hline & Gas & Along the access road & 3 \\
\hline & \multirow[t]{3}{*}{$\begin{array}{l}\text { Retail (clothes, foods, home needs, drinks } \\
\text { etc.) }\end{array}$} & Along the Sam Nujoma Road & 5 \\
\hline & & Along the Bagamoyo Road & 11 \\
\hline & & Along the access road & 15 \\
\hline & \multirow[t]{3}{*}{ Hardware } & Along the access road & 97 \\
\hline & & Along the Bagamoyo Road & 14 \\
\hline & & Along Sam Nujoma Road & 8 \\
\hline & Wholesale (food, drinks and cement & Along the access road & 3 \\
\hline & \multirow[t]{3}{*}{ Stationary } & Along the Bagamoyo Road & 2 \\
\hline & & Along the access road & 18 \\
\hline & & Along Sam Nujoma Road & 2 \\
\hline \multirow[t]{2}{*}{ Butchery } & \multirow{2}{*}{ Meat, Fish, Chicken, } & Along the access road & 6 \\
\hline & & Along the Bagamoyo Road & 1 \\
\hline Filling station & Liquid fuel & Along Sam Nujoma Road & 2 \\
\hline \multirow{3}{*}{$\begin{array}{l}\text { Hawkers (also } \\
\text { with } \\
\text { mobile stalls) }\end{array}$} & \multirow[t]{3}{*}{ Vegetables, fruits, herbal nutrients } & Along Sam Nujoma Road & 3 \\
\hline & & Along the Bagamoyo Road & 107 \\
\hline & & Along the access road & 21 \\
\hline \multirow[t]{3}{*}{ Work shop } & \multirow[t]{2}{*}{ Timber, Steel \& Welding, } & Along the access road & 10 \\
\hline & & Along the Bagamoyo Road & 7 \\
\hline & Tailoring & Along the access road & 9 \\
\hline \multirow{2}{*}{$\begin{array}{l}\text { Food vending } \\
\text { stalls }\end{array}$} & \multirow{2}{*}{$\begin{array}{l}\text { Vegetables, fruits, potatoes, yams, fish, } \\
\text { chapati, vitumbua, french-fries with } \\
\text { scrambled eggs "chops-mayai" }\end{array}$} & Along the main road, access roads & 51 \\
\hline & & $\begin{array}{l}\text { and in front of retail shops } \\
\text { Along Sam Nujoma Road }\end{array}$ & \\
\hline \multirow[t]{3}{*}{ Bar/restaurant } & \multirow[t]{3}{*}{ Drinks/food } & Along Sam Nujoma Road & 3 \\
\hline & & Along the Bagamoyo Road & 2 \\
\hline & & Along the access road & 19 \\
\hline \multirow[t]{3}{*}{ Salon } & \multirow[t]{2}{*}{ Men } & Along the access road & 14 \\
\hline & & Along the Bagamoyo Road & 4 \\
\hline & Women & Along the access road & 18 \\
\hline Banks & Monetary services & Along the Bagamoyo Road & 1 \\
\hline
\end{tabular}

4.21 to 4.36 ), with exceptional of one ( $0.9 \%)$ old aged head of the household, who is living as a dependent to her daughters and a son. The activities which also coincide with writing by Ojong, (2011); Abu-Salia, et al., (2015); Kalugila \& Mbisso, (2018); and Kassa, (2019) includes;- rental; small scale urban agriculture; trading i.e. a number of commercial frames for normal retail shops, butchery, welding and carpentry workshops, street hawking, bars and restaurants; fixed and mobile food vending and processing; fire wood and charcoal business; vehicle, motorbike, motor tricycles (rickshaw or bajaj), motor cycles, and taxi operation and repair; milling machines; building materials hardware; local brewing; baking; fixed and mobile food vending; male salon (barbershop) and female salon (beauty salon); tailoring; paid domestic works, mobile shoe mending, block making and masonry, construction (as "local fundi"); filling station business; banks and mobile money platforms, such as M-PESA, Airtel Money, T-PESA, TiGO PESA, etc. These activities, revealed respondents to have temporary and permanent employment, within and out of Mlalakuwa, with others being self-employed. Through these most people obtain their wages/salaries, alongside evidencing the statement by Farrington, et al., (2002), on how closely 
Dennis N.G.A.K. Tesha/Households Livelihood Coping Strategies in the Urban Informal Settlements; the Case of Mlalakuwa, Dar-es-Salaam, Tanzania.

Financial Capital depend on adequate Human Capital.

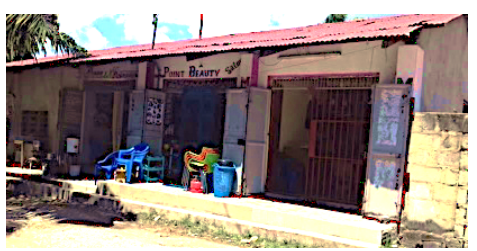

Plate 4.21; the beauty salon and retail shop within Mlalakuwa.

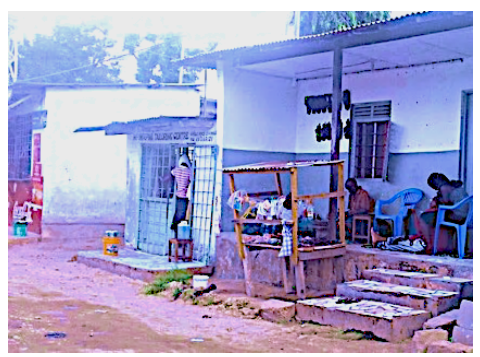

Plate 4.23; a shoe repair, kiosk and retail shops, within Mlalakuwa.

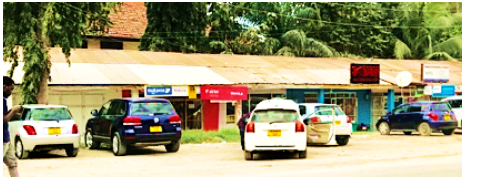

Plate4.25; the retail shops, stationery, mobile money services, and beuty saloon at Mlalakuwa.

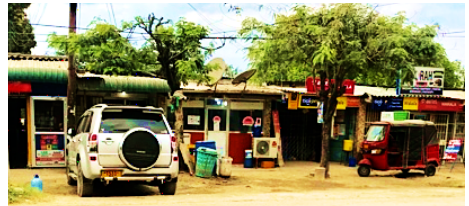

Plate 4.27; the retail shops, stationeries, butchery, male saloon (barbershop), mobile money business, in Mlalakuwa.

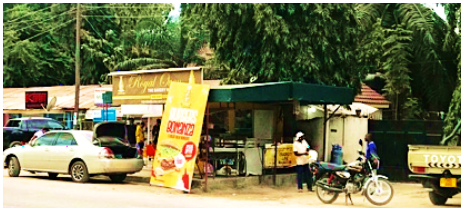

Plate 4.29; the retail shops, beuty saloon, fast-food vending, a mechanical garage in Mlalakuwa.

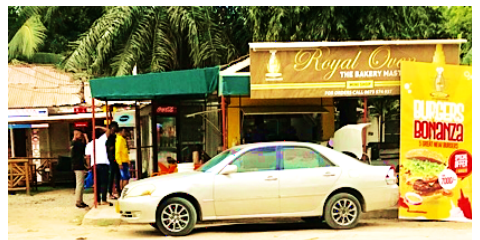

Plate 4.31; the beuty saloon, a retail shop and fast-food vending beside the garage in Mlalakuwa.

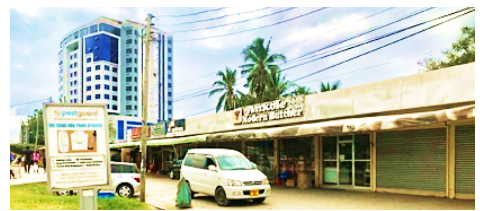

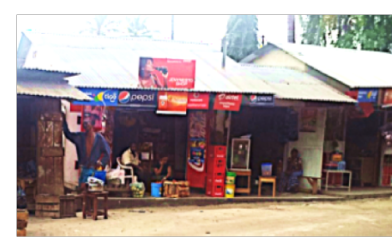

Plate 4.22; thecharcoal busness \& retail shops within Mlalakuwa

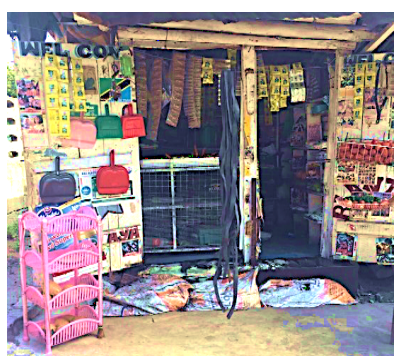

Plate 4.24; a retail shop within Mlalakuwa.

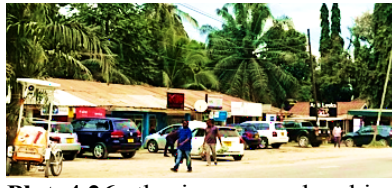

Plate4.26; the ice cream hawking retail shops, stationery, and beuty saloon at Mlalakuwa.

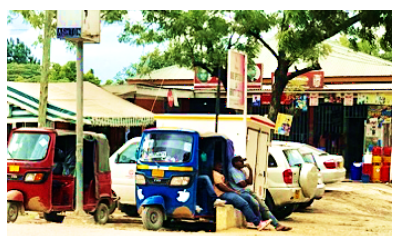

Plate 4.28; the retail shops, motorcycles "bajaj or rickshaw" business, food vending, in Mlalakuwa

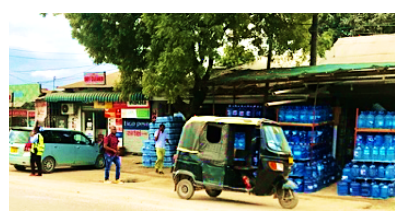

Plate 4.30; the retail shops, dray cleaning and mobile money business in Mlalakuwa.
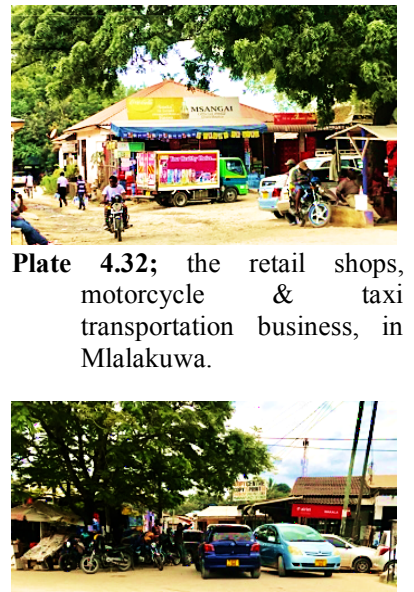

Plate 4.33; retail shops, butchery, minisupermarket, and commercial building in Mlalakuwa.

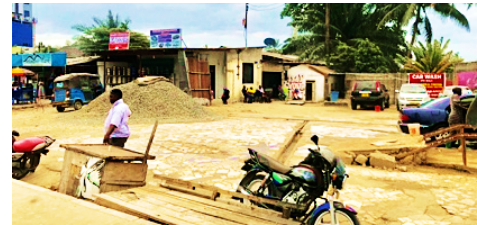

Plate 4.35; the retail shop and car wash business in Mlalakuwa.
Plate 4.34; the retail shops, motorcycles, stationery and food vending in Mlalakuwa.

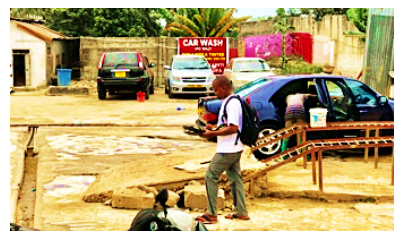

Plate 4.36; a car wash business in Mlalakuwa

The reduction is mostly done on household's type of food to be consumed; fasting and restriction of regular food intake of some family members; reduction of household size; transportation; using herbs from their native village for treatment, instead of modern medicine for cases such as malaria, flu, headache, stomachache, low blood count for pregnant women, heart and diabetic diseases, etc.; drinks; repairs (i.e. housing structure, electrical and plumbing system, etc.); reducing the use of electricity to lower the monthly bills; nonattendance to salon for both male and female; selling home-grown vegetables and other products to the community; selling some unwanted assets, with expectation of buying new ones later, after reimbursing the loan, etc. This accord a study by Cephas \& Bernard, (2012); Calvo \& Dercon, (2005) in Akeweta, et al., (2014); and Endris, et al., (2017).

\subsection{CONCLUSION}

The study intended to know the livelihood coping strategies, which households explore in order to make a living, including how they distribute their productive resources, and the types of activities in which they are engaged in. The households in Malalakuwa urban informal settlement, survive by combining various assets as livelihood coping strategies based on their indigenous strategies and knowledge, so as to recover from daily life stress and shocks; hence indicating the need to promote diversification. Furthermore, findings indicated that; coping strategies are shaped by the constraints under which households operate, and their combination permits them to have several income streams, hence making them more significant than external assistance. The dominant livelihood activities include both agricultural (farm) and nonagricultural (non-farm) activities, such as urban agriculture and livestock keeping (i.e. pigs, chicken and cow), trading goods in the market, shop keeping, selling pharmaceuticals, monetary services (banks, and mobile money), local brewing, running 
female hair dressing or beauty salons and male salon (barbershop) as well as selling their products, vehicle and motor cycles repairing, milling machines, taxi-running and driving, motor cyclesrunning and driving, mobile shoe shining and mending, food processing and vending, food product street hawking, fish and meat butchery, selling fuel wood and charcoal, tailoring and cloth retailing, carpentry, welding and metal working, bricks and pavement material making, building materials retailing, oil and gas trading, etc. In addition to that, findings showed that; land and urban agriculture (natural capital), housing (physical capital) and social network and trust (social capital) were came-up as a major and valuable livelihood assets, for both lower- and middle-income earners within the Mlalakuwa urban informal settlement. The most frequently used coping strategies included; trading various goods and services; collecting rent; reduction households number and food consumption; loan facilities from formal institutions and community-based social groups, etc. The results, should facilitate nongovernmental organization's as well as local and central government authority's interventions; designed to improve household livelihoods.

\section{References:}

[1] Abebe, F.K, (2011); "Modelling Informal Settlement Growth in Dar-es-Salaam, Tanzania" Unpublished Dissertation for the MSc. in Geo-information Science and Earth Observation, Faculty of Geoinformation Science and Earth Observation, the University of Twente, 110 Pages.

[2] Abu-Salia, R., Osumanu, I.K., \& Ahmed, A., (2015); "Coping with the Challenges of Urbanization in Low Income Areas: an Analysis of the Livelihood Systems of Slum Dwellers of the Wa Municipality, Ghana", in the Journal of Current Urban Studies, Vol. 03, Page 105 to 118, Published by Scientific Research Publishing INC, (http://dx.doi.org/10.4236/cus.2015.32010).

[3] Akeweta, N. J., Ndaghu, A.A., \& Kefas, P.D., (2014); "Livelihood as Poverty Coping Strategy of Rural Women in Song Local Government Area, Adamawa State", in the International Journal of Agriculture Innovations and Research (IJAIR), Vol. 03, (01), Page 190 to 197, e-ISSN:2319-1473, (https://ijair.org/administrator/components/com_jres e arch/files/publications/IJAIR_823_Final.pdf).
[4] All-Kamal, M., (2013); "Livelihood Coping and Recovery from Disaster: The Case of Coastal Bangladesh", in the Current Research Journal of Social Sciences, Vol. 05, (01), Page 35 to 44, Published by Maxwell Scientific Organization, pISSN:2041-3238, e-ISSN:2041-3246, (https://dx.doi.org/10.19026/crjss.5.5537).

[5] Amendah, D.D., Buigut, S., Mohamed, S., (2014); "Coping Strategies among Urban Poor: Evidence from Nairobi, Kenya", in the PLoS ONE, Vol. 09, (01): e83428, (http://dx.doi:10.1371/journal.pone.0083428).

[6] Bahendwa, F., (2013); "Urban Form Through Residents' Practices: the Unconventional Transformation Processes in Suburban Areas in Dares-Salaam, Tanzania", ISBN: 9788254702505, Published PhD Thesis, Oslo School of Architecture and Design (AHO), Oslo, Norway, Published By Unipub forlag AS, 286 Pages.

[7] Banks, N., (2015); "Livelihoods Limitations: the Political Economy of Urban Poverty in Dhaka, Bangladesh", in the Journal of Development and Change, Vol. 47, (02), Page 266 to 292, Published by John Wiley \& Sons LTD on behalf of International Institute of Social Studies, (http://dx.doi.org/10.1111/dech.12219).

[8] Bengtsson, M., \& Klerfelt, M., (2014); “Agricultural Intensification and Livelihood Strategies of Female Farmers in Babati District, Tanzania", Unpublished Bachelor Thesis in Human Geography, Environmental Social Science Programme, School of Business, Economics and Law, Department of Economy and Society, University of Gothenburg, Sweden, $70 \quad$ Pages, (https://gupea.ub.gu.se/bitstream/2077/37281/1/gupe a_2077_37281_1.pdf).

[9] Bhattacharjee, M., (2016): "Diversification for Sustainable Livelihood Outcome in India: Macro and Micro Perspectives", in the Journal of Advances in Economics and Business Management (AEBM), Vol. 03, (02), Page 200 to 204, Published by Krishi Sanskriti Publications, p-ISSN:2394-1545; eISSN:2394-1553; (https://serialsjournals.com/abstra ct/19769_ch_32_f_-_mahua.pdf).

[10] Busaeri, S.R., Salman, D., Fahmid, I.M., \& Yusran, (2015); "Household Livelihood Strategies in Bantimurung Bulusaraung National Park Maros District, South Sulawesi Province, Indonesia", in the International Journal of Humanities and Social Science, Vol. 05, (01), Page 278 to 283, Published by Center for Promoting Ideas, p-ISSN:2220-8488, e-ISSN:2221-0989, (http://www.ijhssnet.com/journals /Vol_5_No_1_January_2015/30.pdf). 


\section{Dennis N.G.A.K. Tesha/Households Livelihood Coping Strategies in the Urban Informal Settlements; the Case of Mlalakuwa, Dar-es-Salaam, Tanzania.}

[11] Carney, D., (1998); "Sustainable Rural Livelihoods: What Contribution Can We Make?", Published by Environment \& Urbanization and Department for International Development, London, ISBN:1861920822, 213 Pages.

[12] Cephas, M., \& Bernard, C., (2012); "Effective Livelihood Strategies in Distressed Environments: the Case of Mudzi District of Zimbabwe", in the Current Research Journal of Social Sciences, Vol. 04, (05), Page 362 to 371, Maxwell Scientific Organization Publisher, e-ISSN:2041-3246.

[13] Chambers, R \& Conway G.R., (1991); "Sustainable Rural Livelihoods: Practical Concepts for the $21^{\text {st }}$ Century", Institute of Development Studies (IDS), Discussion Papers No. 296, University of Sussex, Brighton, United Kingdom, (https://publications.iwmi.org/pdf/H_32821.pdf).

[14] Chambers, R., (1995); "Poverty and Livelihoods: Whose Reality Counts?", in the Journal of Environment and Urbanization, Vol. 07, (01), Page 173 to 204, Published by SAGE, (https://doi.org/10.1177\%2F 095624789500700106).

[15] CIA, (2020); "2020 CIA Tanzania-World Fact Book and Other Sources", Washington D.C., USA, (https://www.cia.gov/library/publicati on/the-worldfactbook/geos/print_tz.html).

[16] De-Haan, L.J., (2012); "the Livelihood Approach: a Critical Exploration", in the ERDKUNDE, Vol. 66, (04), Page 345 to 357, ISSN:0014-0015, (http://dx.doi.org/10.3112/erdkunde.2012.04.05).

[17] Department for International Development, (DFID), (1999); "Sustainable Livelihoods Guidance Sheets", 26 Pages, (http://files.ennon line.net/attachments/871/dfid-sustainablelivelihoods-guidance-sheet-sec tion1.pdf).

[18] Ekandem, E.S., Daudu, P.I., Lamidi, R.B., Ayegba, M.O., \& Adekunle, A., (2014); "Spontaneous Settlements: Roles and Challenges to Urban Planning", in the Journal of Sustainable Development Studies, Vol. 06, (02), ISSN: 22014268, Page 361 to 390, (https://infinitypress.info/inde x.php/jsds/article/download/760/377).

[19] Ellis, F., (2000); "Rural Livelihoods and Diversity in Developing Countries", Published by Oxford University Press, (OUP), p-ISBN:9780-1982-96966, 292 Pages, Oxford, United Kingdom.

[20] Ellis, F., (1999); "Rural Livelihood Diversity in Developing Countries: Evidence and Policy Implications", in the Journal of Natural Resource Perspectives, Issue (40), Page 01 to 10, Published by DFID, (https://www.odi.org/sites/odi.org.uk/files/odiassets/p ublications-opinion-files/2881.pdf).

[21] Ellis, F., (1998); "Household Strategies and Rural Livelihood Diversification" in the Journal of Development Studies, Vol. 35, (01), Page 01 to 38, (https://doi.org/10.1080/00220389808422553).

[22] Endris, G.S., Kibwika, P., Hassan, J.Y., \& Obaa, B.B., (2017); "Harnessing Social Capital for Resilience to Livelihood Shocks: Ethnographic Evidence of Indigenous Mutual Support Practices among Rural Households in Eastern Ethiopia”, in the International Journal of Population Research, Vol, 2017, Article ID 4513607, 26 Pages, Published by Hindawi, n(https://dx.doi.org/10.1155/2017/4513607). Also presented on the African Unity and Renaissance Conference and Africa Day Expo held in Pretoria, South Africa, May 21-25, 2017, Pages 58-59, (http://www.hsrc.ac.za/uploads/pageContent/8184/A UR\% 20Book\%20of\%20Abstract fa.pdf).

[23] Eneyew, A., \& Bekele, W., (2012); "Determinants of Livelihood Strategies in Wolaita, Southern Ethiopia”, in the Journal of Agricultural Research and Reviews, Vol. 01,(05), Page 153 to 161.

[24] Fang, Y., Fan, J., Shen, M., \& Song, M., (2014); "Sensitivity of Livelihood Strategy to Livelihood Capital in Mountain Areas: Empirical Analysis Based on Different Settlements in the Upper Reaches of the Minjiang River, China", in the Journal of Ecological Indicators, Vol. 38, Page 225 to 235, Published by Science Direct \& Elsevier LTD.,

(http://dx.doi.org/10.1016/j.ecolind.2013.11.007).

[25] Farrington, J., Ramasut, T., \& Walker, J., (2002); "Sustainable Livelihoods Approaches in Urban Areas; General Lessons, with Illustrations from Indian Cases", Working Paper 162, Published by Overseas Development Institute (ODI), Westminster, London, United Kingdom, ISBN: 085003-576-7, 53 Pages, (https://www.odi.org/sites/ odi.org.uk/files/odi-assets/publications-opinionfiles/2706.pdf).

[26] Frankenberger, R.T., Luther, K., \& McCaston, M.K., (2002); "Household Livelihood Security Assessments;- a Toolkit for Practitioners", 42 Pages, CARE-U.S.A. PHLS, Published by TANGO International Inc., Tucson, Arizona, (https://scarp.ubc.ca/sites /scarp.ubc .ca/files/Household-Livelihood-Assessment.pdf).

[27] Hamdi, N., (2017); "Housing Without Houses: Participation, Flexibility and Enablement", Published by Practical Action Publishing, Oxford, 


\section{Dennis N.G.A.K. Tesha/Households Livelihood Coping Strategies in the Urban Informal Settlements; the Case of Mlalakuwa, Dar-es-Salaam, Tanzania.}

United Kingdom, ISBN-10:1853392928 ISBN13:9781853392924.

[28] Han, Z., Ba, Z., \& Xin, R., (2015); "Livelihood Losses, Recovery, and Opportunities for Cultural Revitalization; Experience from the 2008 Wenchuan Earthquake in People's Republic of China", Chapter 10 from Page 141 to 153, a Chapter in the Book, titled "Disaster's Impact on Livelihood and Cultural Survival; Losses, Opportunities, and Mitigation", by Michele Companion, (2015), Published by CRC Press is an Imprint of Taylor \& Francis Group LLC, e-ISBN-13: 978-1-4822-4844-9, 350 Pages.

[29] Haviland, W.A., (2013); "Cultural Anthropology: the Human Challenge", Belmont, CA: Published by Wadsworth/Thomson Learning, 434 Pages, 14 ${ }^{\text {th }}$ Edition, ISBN-13:978-1-133-95742-3.

[30] Haviland, W.A., (2003); “Anthropology”, Published by Wadsworth/Thomson Learning, 839 Pages, $10^{\text {th }}$ Edition Illustrated, ISBN:978-0-534-61020-3.

[31] Henderson, J.V., Roberts, M., \& Storeygard, A., (2013); "Is Urbanization in Sub-Saharan Africa Different?", a Policy Research Working Paper Series 6481, the World Bank, 48 Pages, (https://pdfs.semanticscholar.org/a58f/12e6a26e1bf0 d779622f04188791c283c608.pdf).

[32] Juma, N., \& Babere, N., (2019); "Informality in Urban Areas, a Case of Land Use Transformation in Mlalakuwa Settlement, Dar-es-Salaam", a Conference Paper, Conference on Land Policy in Africa (CLPA-2019), Winning Fight Against Corruption in the Land Sector: Sustainable Pathway for Africa's Transformation 25 - 29 November, 2019, Abidjan, Cote d'Ivoire, 14 Pages, (https://www.uneca.org/sites/default/files/uploadeddocuments/CLPA/2019/Papers/Rapid-Urbanizationsustainable-land-use/paper_clpa_2019.pdf).

[33] Kalugila, S.L., \& Mbisso, A.D., (2018); 'Developers' Preferences to Types of Emerging Landed Properties in Informal Urban Settlements: Case of Mlalakuwa - Dar-es-Salaam", in the International Journal of Development Research, Vol. 08, (04), Page 20027 to 20034, ISSN: 2230-9926, (https://www.journalijdr.com/sites/default/files/issue -pdf/1 2799.pdf).

[34] Kalugila, S.L., (2014); "Housing Interventions and its Influence on Urban Development: Opportunities and Challenges in Mixed Informal Settlements, in Dar-es-Salaam, Tanzania", Published Ph.D. Thesis, Faculty of Architecture, Bauhaus-Universität, Weimar, Germany, $304 \quad$ Pages, (https://core.ac.uk/download/pdf/53141483.pdf).

[35] Beall， J., \& Kanji, N., (1999); "Households, Livelihoods and Urban Poverty", a Background
Paper for the ESCOR Commissioned Research on Urban Development: Urban Governance, Partnership and Poverty, Department of Social Policy and Administration, London School of Economics and Political Science, 42 Pages.

[36] Kassa, W.A., (2019); "Determinants and Challenges of Rural Livelihood Diversification in Ethiopia: Qualitative Review", in the Journal of Agricultural Extension and Rural Development (JAERD), Vol.11, (02), Page 17 to 24, e-ISSN:2141-2170, (https://dx.doi.org/10.5897/JAERD2018.0979).

[37] Kikwasi, G.J., \& Mbuya, E., (2019); "Vulnerability Analysis of Building Structures to Floods: the Case of Flooding Informal Settlements in Dar-es-Salaam, Tanzania", in the International Journal of Building Pathology and Adaptation, Emerald Publishing Limited, (https://dx.doi.org/10.1108/IJBPA-072018-0056).

[38] Kiondo, M.I., \& Mosha, L.H., (2017); "Synthesis of Human Settlement Layers in Mbeya City in Tanzania", International Journal of Recent Scientific Research, Vol. 08,(03), Page 16194 to 16199, ISSN: 0976-3031, (http://dx.doi.org/10.24327/ijrsr.2017.0803.0096).

[39] Kiunsi, R., (2013); "the Constraints on Climate Change Adaptation in a City with a Large Development Deficit: the Case of Dar-es-Salaam", in the Journal Environment \& Urbanization, Vol. 25, (02), Page 321 to 337, Published by International Institute for Environment and Development (IIED), and SAGE Publication, (http://dx.doi.org/10.1177/0956247813489617).

[40] Kombe, W.J., \& Kreibich V., (2000); "Formal Land Management in Tanzania", the SPRING Research Series No. 29, University of Dortmund, Dortmund, Germany.

[41] Kombe W.J., \& Kreibich V., (2000); "Informal Land Management in Tanzania", the SPRING Research Series No. 29, University of Dortmund, Dortmund, Germany.

[42] Kombo, D.K., \& Tromp, D.L.A., (2014); "Proposal and Thesis Writing; an Introduction" $14^{\text {th }}$ Edition, Published by Paulines Publication Africa, ISBN:9966-08-133-X, Nairobi- Kenya, 168 Pages.

[43] Kothari, C.R., (2019); "Research Methodology, Methods and Techniques", $4^{\text {th }}$ Revised Edition, Daryaganj, New Delhi, India: New Age International (Pvt) Limited Publishers, ISBN: 9789386649225, 401 Pages.

[44] Kumar, R., (2011); "Research Methodology: a Step by Step Guide For Beginners", $3^{\text {rd }}$ Revised Edition, New Delhi, India, Los Angeles and Washington DC, 
USA, London, United Kingdom, Published by SAGE Publication Pvt LTD.

[45] Kyessi, A.G., (2000); "Community Participation in Urban Infrastructure Provision: Servicing Informal Settlements in Dar-es-Salaam, Tanzania", Published Ph.D. Thesis, Faculty of Spatial Planning. Dortmund: University of Dortmund, Germany.

[46] Kyessi, A.G., (2013); "Changing Urban Environments: Challenges and Opportunities of Rapidly Urbanizing Africa in the Context of Climate Change: the Case of Tanzania", Paper presented in an International Conference on Challenges of Urbanization and Development in Africa in the Context of Climate Change", Held in Arusha, July 24 to $26,2013$.

[47] Kyessi, $\quad$ S.A., \& Kyessi, A.G., (2007); "Regularisation and Formalisation of Informal Settlements in Tanzania: Opportunities and Challenges: a Case of Dar-es-Salaam City", Paper Presented in an International Conference, Hong Kong.

[48] Layson, J.P., (2013); "Integrating Community Participation in Urban Redevelopment Projects; the Case of Makongo in Dar-es-Salaam, Tanzania", the $49^{\text {th }}$ ISOCARP Congress, Tongji University, China, 12

(http://www.isocarp.net/Data/case_studies/2342.pdf)

[49] Limbumba, T.M., (2010); "Exploring social-cultural explanations for residential location choices; the Case of an African City, Dar-es-Salaam", Royal Institute of Technology, (KTH), School of Architecture and the Built Environment, Department of Urban Planning and Environment, Built Environment Analysis, Published Ph.D. Dissertation, KTH, Stockholm, Sweden, ISBN: 978-91-7415-5815, 243 Pages.

[50] Lupala, J.M., \& Maglan, S.C., (2015); “Climate Change and Its Effects on Livelihood Strategies of Peri-Urban Coastal Communities in Tanzania", in the Pyrex Journal of Geography and Regional Planning, Vol. 01, (01), Page 001 to 010, Published by Pyrex, (http://www.taccire.suanet.ac.tz/xmlui/bitstream/han dle/123456789/499/LUPALA.pdf?sequence=1).

[51] Lupala, J.M., \& Kiunsi, R., (2011); "Dar-es-Salaam City, 50 years to Come: Conceptual Considerations", Unpublished Workshop Working Paper Presented During the 50 Years Anniversary of the University of Dar-es-Salaam, Tanzania.

[52] Lupala, J.M., (2002); "Urban Types in Rapidly Urbanizing Cities, Analysis of Formal and Informal Settlements in DSM Tanzania", Published Ph.D. Thesis, Division of Urban Studies, Department of
Infrastructure, The Royal Institute of Technology, Sweden, 280 Pages.

[53] Magigi, W., (2016); "Methodological Tools For Researching and Scientific Writing in Emerging Economies; A Guide to Understand Research Process, Proposal Writing, Data Collection, Analysis and Scientific Writing", Published by Safi Publishers and Trading Co. LTD, Tanzania, ISBN:9789987778119, 446 Pages.

[54] Magigi, W., \& Majani, B.B.K., (2006); “Community Involvement in Land Regularization for Informal Settlements in Tanzania: A Strategy for Enhancing Security of Tenure in Residential Neighborhoods", in the Journal of Habitat International, Vol. 30, (04), Published By Elsevier LTD, Page 1066 to 1081, (https://doi.org/10.1016/j.habitatint.2005.12.002).

[55] Makalle, A.M., Mesaki, S., \& Victor, M.A., (2011); "Livelihood Opportunities Through Informal Housing in the New Capital City of Dodoma, Tanzania", in the Journal Cross-cultural Communication, Vol. 07, (04), Page 104 to 120, ISSN-print:1712-8358, ISSN-online:1923-6700, (https://doi.org/10.3968/j.ccc.1923670020110704.26 2).

[56] Mbisso, D.A., \& Kalugila, S.L., (2018); "Trading Facilities and Socio-spatial Character of Informal Settlements; the Case of Mlalakuwa in Dar-esSalaam, Tanzania", in the Journal of Sustainable Development, Vol. 11, (02), Page 141 to 148, Published by Canadian Center of Science and Education, p-ISSN:1913-9063 e-ISSN:1913-9071, (https://doi.org/10.5539/jsd.v11n2p141).

[57] Mosha, L.H., (2017); "Questioning the Concept of Affordable Housing - Affordable to Who in Tanzania?", in the International Journal of Recent Scientific Research, Vol. 08, (05), Page 16866 to 16871, ISSN: 0976-3031, (http://dx.doi.org/10.24327/ijrsr.2017.0805.0233).

[58] Msuya, S.M., Mosha, P.E., \& Mtili, R.A., (2017); "the Challenges of Development Control of Informal Settlements in Arusha City; a Case of Ngaranaro Ward", in the International Journal of Innovation and Scientific Research, Vol. 32, (01), Page 166 to 172, Published by Innovative Space of Scientific Research Journals, ISSN: 2351-8014, (http://www.issr-

journals.org/links/papers.php?journal=ijisr\&applicati on $=$ pdf \& article $=$ IJISR-17-038-04).

[59] Mushumbusi, M.Z, (2011); "Formal and Informal Practices for Affordable Urban Housing; Case Study, Dar-Es-Salaam, Tanzania", Doctoral Thesis in Infrastructure, Published by Kungliga Tekniska Högskolan (KTH), Stockholm, Sweden, ISSN 1653- 


\section{Dennis N.G.A.K. Tesha/Households Livelihood Coping Strategies in the Urban Informal Settlements; the Case of Mlalakuwa, Dar-es-Salaam, Tanzania.}

6126, ISRN KTH/SoM/11 -02/SE, ISBN 978-917415-882-3, (http://www.kth.se/), 189 Pages.

[60] Nikuze, A., Sliuzas, R., Flacke, R., \& Van Maarseveen, M., (2019); "Livelihood Impacts of Displacement and Resettlement on Informal Households - A Case Study from Kigali, Rwanda", in the Habitat International Journal, Vol. 86, Page 38 to 47, Published By Science Direct and Elsevier LTD,

(https://doi.org/10.1016/j.habitatint.2019.02.006).

[61] Nguluma, H.M., \& Kemwita, F.E., (2018); "Housing Design for Elderly People in Tanzania; Significance of Adaptable Housing", in the International Research Journal of Advanced Engineering and Science, Vol. 03, (02), Page 355 to 362, e-ISSN: 2455-9024, (https://www.irjaes.com/pdf/V3N2Y18IRJAES/IRJAES-V3N2P1052Y 18.pdf).

[62] Nguluma, H.M., (2006); "the Role of Mafundi in Housing Construction in Informal Settlements in Dar-es-Salaam", in the Journal of Building and Land Development, Vol. 13, (02), Page 84 to 93, Published by African Journal Online (AJOL), eISSN: 0856-0501, (https://doi.org/10.4314/jbld.v13i2.41411).

[63] Nguluma, H.M., (2003); "Housing Themselves: Transformation, Modernisation and Spatial Qualities in Informal Settlements in Dar-es-Salaam, Tanzania”, Royal Institute of Technology, (KTH), School of Architecture and the Built Environment, Department of Urban Planning and Environment, Built Environment Analysis, Published Ph.D. Dissertation, KTH, Stockholm, Sweden.

[64] Nnkya, T., \& Lupala, J., (2010); "Planning Education in Tanzania: the Experience of Ardhi University", in the Journal of Building and Land Development, Special Issue, Page 157 to 173.

[65] OECD, (2013); "Standard Concepts, Definitions and Classifications for Household Wealth Statistics", Chapter \#03 of the OECD Guidelines for Micro Statistics on Household Wealth, Page 41 to 97, Published by OECD, Paris, France, (https://doi.org/10.1787/9789264194878-en).

[66] Ojong, N., (2011); "Livelihood Strategies in African Cities: the Case of Residents in Bamenda, Cameroon", in the Journal of African Review of Economics and Finance, Vol. \#03, (01), Page 08 to 25, Published By the Publishing Centre, African Centre for Economics and Finance, Rhodes University, Grahamstown, South Africa, (https://www.african-

review.com/journal/v3(1)december2011/Livelihood $\% 20$ strategies\%20in\%20African\%20cities.pdf).
[67] Oluwafemi, O., (2013); "Poverty Alleviation in Lagos Urban Informal Settlements: A Sustainable Livelihood Approach", A Paper Presented at the $49^{\text {th }}$ ISOCARP Congress on Sustainable Livelihood Approach to Poverty Alleviation, 12 Pages, (http://www.isocarp.net/Data/case_studies/2374.pdf)

[68] Parsa, A., Nakendo, F., McCluskey, W.J., \& Page, M.W., (2010); "Impact of Formalisation of Property Rights in Informal Settlements: Evidence from Dares-Salaam City", in the Journal of Land Use Policy, Vol. 28, (04), Page 695 to 705, (https://doi.org/10.1016/j.landusepol.2010.12.005).

[69] Rakodi, C., \& Lloyd-Jones, T., (2002); “A Livelihoods Approach Conceptual Issues and Definitions", Chapter One in Rakodi, C., \& LloydJones, T., (Eds.): Urban Livelihood; a Peoplecentred Approach to Reducing Poverty, Published by Taylor \& Francis Group, Page 03 to 22 Pages.

[70] Rasmussen, M.I., (2013); "the Power of Informal Settlements. The Case of Dar-Es-Salaam, Tanzania", in the Journal of Urbanism, Vol. 01, (26), Cities to be termed? Standard and Alternatives in the Transformation of the Urban South Conference Proceedings, Published by Planum, ISSN 17230993, Page 01 to 11.

[71] Rafea, N., (2017); "Livelihood Coping Strategies of Women Heads of Households in Cairo's Informal Settlements: the Case of Izbet El Haggana", Published Masters of Political Science Thesis, Department of Political Science, School of Humanities and Social Sciences, the American University in Cairo, 95 Pages, (https://pdfs.semanticscho

lar.org/abc5/e3ced594882f253c074f9453409695019 ef4.pdf?.ga=2.27249789.1196466108.1588001271339894083.1545142831).

[72] Ricci, L., (2019); "Peri-Urban Livelihood and Adaptive Capacity: the Case of Dar es Salaam", Consilience: the Journal of Sustainable Development, Vol. 21, (01), Page 121 to 139, Published by Columbia University \& JSTOR, (https://www.jstor.org/stable/pdf/26775087.pdf?r efreqid $=$ excelsior $\% 3 \mathrm{~A} 73 \mathrm{dff} 12 \mathrm{e} 5 \mathrm{~d} 0 \mathrm{dc} 662 \mathrm{de} 3 \mathrm{e} 8694 \mathrm{~b}$ 39b43b0).

[73] Rweyemamu, V., (2013); "Informalizing Formal Urban Settlements; the Case of Sinza, Dar-esSalaam, Tanzania", Unpublished Masters Dissertation, the College of Engineering, Design, Art and Technology (CEDAT), School of Built Environment, Department of Architecture and Physical Planning, Makelele University, Kampala, Uganda. 
[74] Sakijege, T., Sartohadi, J., Marfai, M.A., Kassenga, G., \& Kasala, S., (2014): "Government and Community Involvement in Environmental Protection and Flood Risk Management: Lessons from Keko Machungwa, Dar-es-Salaam, Tanzania”, in the Journal of Environmental Protection, Vol. 05, Page 760 to 771, Published by Scientific Research Publishing (http://dx.doi.org/10.4236/jep.2014.59078).

[75] Sakijege, S.T., (2013); "Managing Flood Risks: Lessons From Keko Machungwa Informal Settlement in Dar-es-Salaam, Tanzania", in the Indonesian Journal of Geography, Vol. 45, (01), Published by the Indonesian Geographers Association, ISSN:0024-9521, Pages 01 to 14, (https://dx.doi.org/10.22146/ijg.2402).

[76] Sheuya, S., (2004); "Housing Transformations and Urban Livelihoods in Informal Settlements; the Case of Dar-es-salaam, Tanzania", Published PhD Thesis, Spring Research Series No. 45 Dortmund, Germany, 214 Pages.

[77] Teyanga, J.J., \& Mrema, L.K., (2018); "Residents' Elements of Legibility of Informal Settlements; the Case of Mlalakuwa Informal Settlement in Dar-esSalaam, Tanzania", in the World Journal of Research and Review (WJRR) Vol. 06, (06), Pages 66 to 79, ISSN:2455-3956, (https://media.neliti.com/media/publications/262636 -residentsand39-elements-of-legibility-of$5 \mathrm{c} 0 \mathrm{cb} 647 . \mathrm{pdf})$.

[78] United Nations, (UN), (2017); "Household Size and Composition Around the World 2017 - Data Booklet", Department of Economic and Social Affairs, Population Division, 36 Pages, (https://www.un.org/en/de

velopment/desa/population/publications/pdf/ageing/ household_size_and_composition_around_the_worl d_2017_data_booklet.pdf).

[79] United Nations Human Settlements Programme (UN-HABITAT), (2011); "Rental Housing: a Much Neglected Housing Option for the Poor", In a Book Series on Housing the Poor in African Cities, Published by United Nations Human Settlements Programme (UN-HABITAT), Training and Capacity Building Branch (TCBB), ISBN Number: (Volume) 978-92-1-132322-1, ISBN Number (Series): 978-921-131926-2, Series 07, 38 Pages.

[80] United Nations Human Settlements Programme (UN-HABITAT), (2010); "Informal Settlements and Finance", United Nations Human Settlements Programme, ISBN: 9789211320275 , ISBN: 9211321869, Earthscan Publications LTD , 66 Pages, (https://unhabitat.org/ books/informal- settlements-and-finance-in-dar-es-salaamtanzania/\#).

[81] United Nations Human Settlements Programme (UN-HABITAT), (2003); "the Challenge of Slums Global Report on Human Settlements 2003", United Nations Human Settlements Programme, ISBN: 184407-037-9 Paperback, ISBN: 1-84407-036-0 Hardback, Earthscan Publications LTD, 310 Pages.

[82] United Nations Development Programme (UNDP), (2017); "Guidance Note for the Application of the Sustainable Livelihoods Framework in Development Projects", Regional Centre for Latin America and the Caribbean, Panama City, Panama, 21 Pages, (https://www.undp.org/content/dam/rblac/docs/Rese arch\%20and\%20Publications/Poverty\%20Reduction /UNDP_RBLAC_Livelihoods\%20Guidance\%20Not e_EN-210July2017.pdf).

[83] United Nations Development Programme, (UNDP), (2015); “Tanzania Human Development Report 2014; Economic Transformation for Human Development", Published by Economic and Social Research Foundation, (ESRF), Ministry of Finance, DSM, United Republic of Tanzania, p-ISBN: 9789987-770-00-7, $128 \quad$ Pages, (http://hdr.undp.org/sites/default/files/thdr2014main.pdf).

[84] United Republic of Tanzania, (URT), (2016a); "Dares-Salaam City Master Plan 2016 - 2036”, Ministry for Lands, Housing and Human Settlements Development (MLHHSD), Government Printers, DSM, Tanzania, 244 Pages.

[85] United Republic of Tanzania, (URT), (2016b); "Tanzania Demographic and Health Survey and Malaria Indicator Survey 2015 - 2016", National Bureau of Statistics(NBS), Government Printers, DSM, Tanzania.

[86] United Republic of Tanzania, (URT), (2013); “2012 Population \& Housing Census", National Bureau of Statistics(NBS), Government Printers, DSM, Tanzania.

[87] United Republic Of Tanzania, (URT), (2012); "Formalization of Informal Urban Settlements in Tanzania", Published by Property and Business Formalization Programme, "MKURABITA Innovations" Government Printers, DSM, 16 Pages, (www.mkurabita.go.tz).

[88] United Republic of Tanzania, (URT), (2010); "Composite Development Goal for the Tanzania Development Vision 2025", Government Printers, DSM, Tanzania.

[89] United Republic of Tanzania, (URT), (2007); "Tanzania Housing Policy Draft III of 2007", 
Dennis N.G.A.K. Tesha/Households Livelihood Coping Strategies in the Urban Informal Settlements; the Case of Mlalakuwa, Dar-es-Salaam, Tanzania.

Ministry of Lands, Housing and Human Settlements (MLHHSD), DSM, Tanzania.

[90] Xu, D., Zhang, J., Rasul, G., Liu, S., Xie, F., Cao, M, \& Liu, E., (2015); "Household Livelihood Strategies and Dependence on Agriculture in the Mountainous Settlements in the Three Gorges Reservoir Area, China", in the Journal of Sustainability, Vol. 07, Page 4850 to 4869, Published by MDPI, e-ISSN:2071-1050, (https://dx.doi.org/10.3390/su7054850). 